\title{
The Structure of Mesoxylon multirame.
}

BY

D. H. SCOTT, F.R.S.

With Plates XI-XIV and two Figures in the Text.

\section{Contents.}

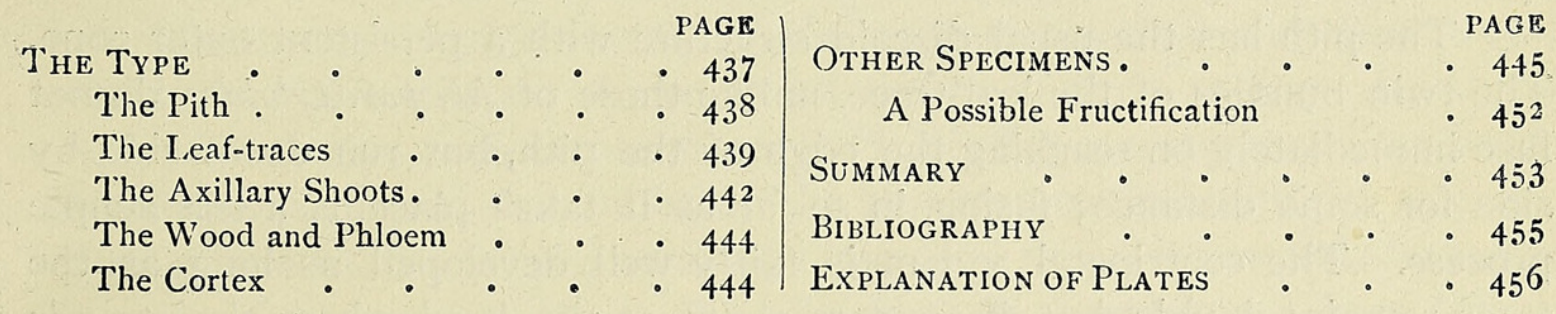

$\mathrm{T}$ continuation of the description of the Coal Measure genus Mesoxy1 lon (Scott and Maslen, 1910; Maslen, 1911; Scott, 1912) an account is given in the present communication of the species $M$. multirame, one of those briefly characterized in the Preliminary Note of I9I0. It will be remembered that the genus Mesoxylon differs essentially from Cordaites in the presence of centripetal wood in the stem.

\section{The TyPe.}

Several specimens of the species now to be described, Mesoxylon multirame, are known. In the first instance I propose to deal with the typespecimen, on which the short description in the Note by Mr. Maslen and myself (I910) was based; this was received from Mr. Lomax in April, 1907. There are 15 transverse and 6 longitudinal sections (Nos. 2329-2343 and 2344-2349 in my collection). The transverse series is remarkably good for following the course of the leaf-traces and axillary steles; the latter accompany the great majority of the leaf-traces. ${ }^{1}$

The diameter of the stem is about $2.5-2.7 \mathrm{~cm}$., that of the pith about $12.5 \mathrm{~mm}$. The stem is a rather young one, the wood only reaching a thickness of about $2.5 \mathrm{~mm}$. and the phloem and pericycle together about I $\mathrm{mm}$. The cortex is from 3 to $3.5 \mathrm{~mm}$. thick. The leaf-traces are numerous and succeed one another very rapidly, so that two or three are often

1 The true order of the transverse sections, from above downwards, follows the numbers with two exceptions-2335 comes above 2334 and 2342 above $234 \mathrm{r}$.

[Annals of Botany, Vol. XXXIr. No. CXXVII. July, 19ı8.] 
cut in a transverse section almost at the same point of their course. That the leaf-bases were fairly crowded is shown by the tangential section 2344 (Pl. XI, Fig. 6). Twenty-six traces were actually observed in the transverse series, representing less than two inches of stem; the true number in this length was obviously greater, as the first three sections are very incomplete. It has not been possible to determine the phyllotaxis in this specimen; the number of orthostichies, provisionally estimated at thirteen in the Preliminary Note, was no doubt higher-possibly twenty-one, though the observed divergences do not agree with an $\frac{8}{21}$ phyllotaxis.

$M$. multirame, like $M$. poroxyloides, is derived from the ordinary coalballs or seam-nodules, occurring in the actual coal. The preservation of the type-specimen is decidedly good, though not equal to that of another specimen, since discovered, which will be referred to later.

The pith has the usual discoid structure with a persistent outer zone. The $t$ win bundles of the leaf-trace, unlike those of $M$. poroxyloides, do not fuse immediately on reaching the edge of the pith, but run down side by side for some distance; fusion, in so far as it takes place, is a less simple process. The centripetal xylem is fairly well developed as long as the trace remains double, but disappears about at the level where the strands become merged. The secondary wood, phloem, and pericycle agree very nearly with those of $M$. poroxyloides. The outer cortex has the usual Dictyoxylon structure, which in the type-specimen is very well differentiated. The subdivision of the leaf-trace, in passing through the cortex, into eight bundles is clearly shown.

A great feature of the species is the presence of axillary shoots. In the type-specimen they are present in connexion with ig out of the 26 leaftraces observed in the transverse series; they appear to be absent from the 7 traces towards the top of the piece of stem, so they were no doubt definitely localized. Their peculiar structure, very different from that of the axillary buds of $M$. Sutcliffi, will be described below (p. 442).

All the best-preserved specimens of $M$. multirame show axillary shoots, but this cannot be used as a specific character, for we cannot doubt that if more material of $M$. Lomaxii and $M$. poroxyloides were available, these species also would prove to have branched in a similar manner.

\section{The Pith.}

In the type-specimen the pith is only moderately well preserved; it is much more perfect in the large stem to be described later. The structure is of the ordinary discoid type (Pl. XIII, Fig. I7), not compound, as observed in $M$. poroxyloides. The more internal cells of the persistent zone, so far as they are preserved, appear nearly empty, while those of the outer part are filled with dense, dark-brown cell-contents (Pl. XI, Figs. 2, 5). Most of the cells are more or less elongated vertically, and this is especially the case 
with the outermost pith-cells which border on the wood. These cells, like their neighbours, usually have dark contents. The cells of the diaphragms are much larger and have a different shape, their greater diameter being horizontal. In the middle part of the diaphragms the cells have collapsed and their walls are often torn.

As usual the diaphragms became much thicker towards the periphery. In this case, however, there is often a constriction between the thickest part of the diaphragm and its abutment on the persistent outer zone. Two adjacent diaphragms sometimes unite in this region-a slight approach to the compound condition found in $M$. poroxyloides. There is no important difference in pith-structure between $M$. multirame and $M$. Sutcliffii.

\section{The Leaf-traces.}

The most valuable feature of the type-specimen is the clear way in which the leaf-traces are shown at all points of their course. In a good transverse section, such as that shown in Pl. XI, Fig. I, many traces can be seen in various positions; but probably the best way to deal with the subject of their course will be to take some one trace and follow it downwards through a series of transverse sections. The illustrations, however, are from different traces, selected as showing the structure best at the various levels figured, for of course we cannot expect the same trace to be equally favourable at all points of its course.

We will take the trace which is numbered ${ }_{3} 3$ in the diagram, Pl. XIII, Fig. 16 .

This first appears in section 2335.

Naturally the axillary shoot precedes the subtending trace in approaching the stem and is alone seen in this section (PI. XI, Fig. 2). The shoot is here partly attached to the cortex of the main stem. It shows the usual extremely flattened stele and parenchymatous cortex with no visible appen. dages. Three such steles are shown, as it happens, in this section-they are all represented in the photograph, Pl. XI, Fig. 2, and the best of them more in detail in the drawing, Pl. XIII, Fig. 22. The stele measures about $3.5 \mathrm{~mm}$. in length (tangential to main stem) by scarcely $0.25 \mathrm{~mm}$. in width.

In the next section below (2334) (diagram, Pl. XIII, Fig. I6), the axillary shoot has completely joined on to the stem and its stele is seen about halfway through the cortex. The subtending leaf-base has now appeared (though badly preserved) to the exterior of the axillary stele, and at least 7 of the 8 bundles of the leaf-trace are recognizable (see diagram, Pl. XIII, Fig. I6, and cf. Fig. 18). The axillary stele is here less flattened, its dimensions being about $2.5 \times 0.75 \mathrm{~mm}$. (cf. the detailed drawing of another stele in Fig. 2I).

Proceeding downwards, section 2336 shows the axillary stele (here little more than $\mathrm{I} .5 \mathrm{~mm}$. in tangential diameter) in the phloem-zone, but its 
adaxial elements are oblique and in the act of joining those of the wood of the main stem. The bundles of the subtending leaf-trace are seen in the cortex, outside the periderm; not all are preserved (five are visible), and it is possible that some fusion among the original eight had already occurred. A somewhat similar stage, but rather lower down, is shown, from another trace, in the photograph, Pl. XI, Fig. 3. In the latter case the leaf-trace bundles have already united so far as to form two symmetrical pairs. In both instances the lateral connexion of the wood of the axillary stele with the stem-wood on either side is well shown.

In the next lower section (2337) the trace, No. I3, has passed within the periderm, and is entering the phloem. Its strands have now united into the pair of bundles characteristic of the trace in the lower part of its course (cf. Pl. XI, Fig. 4, from another trace). The stem-wood behind the leaftrace is still disturbed, owing to its junction with that of the axillary stele. A pith-bay intrudes into the wood at this level; and a definite median strand of xylem lies directly below the attachment of the axillary stele.

In the next section below (2338) the double trace is just entering the secondary wood, the twin bundles passing in on either side of the median strand, with which they are connected by oblique elements.

One section lower (2339) the twin bundles, converging slightly, have almost reached the pith. There is a space between them, almost equal to the width of a bundle, which is still occupied by the median strand. Almost the same condition, from another trace, is shown from a photograph in Pl. XI, Fig. 5. The bundles at this level have well-developed centripetal xylem; there is no definite sheath, though sometimes a few short tracheides are found in the tissue on the inner side of the bundles.

At the next lower level (2340) the double trace has definitely taken up its position on the inner edge of the wood, bordering on the pith, into which the two strands project somewhat. They are nearer together than before, and the median strand between them is no longer well marked; it stops short of the pith. The bundles of the trace retain their centripetal wood with little if any diminution. A similar stage is shown in Pl. XIII, Fig. I9.

One section below again (2342) the trace still forms a prominent pair; the twin bundles are quite distinct but approximated; near the pith a biseriate ray separates them. The median strand has split up, and its tracheal rows on either side have joined the wood of the twin strands, from which they can no longer be distinguished. The position of the protoxylem is difficult to make out; but the centripetal wood is evidently much reduced, nearly the whole xylem belonging to the radial centrifugal series.

The next section (234I) shows an interesting change. The two bundles of the trace are no longer distinct ; the trace is here represented by a single broad xylem-mass projecting into the pith. The mass is made up of seven radial bands of tracheides, separated by medullary rays. There is no longer 
any distinction between the trace-bundles and the median strand; all three have split up and rearranged their parts so as to form a single whole. The structure appears to have become endarch as shown in Pl. XIII, Fig. 20, which represents another trace at about the same level.

In the lowest section, 2343, the trace is less prominent, and some more fusion among the various tracheal bands has taken place.

It will be seen that in the behaviour of the trace-bundles after reaching the border of the pith there are considerable differences from $M$. Lomaxii and $M$. poroxyloides; in the former species the twin bundles fuse immediately on attaining this position; the centripetal xylem persists far below the point of fusion. In $M$. poroxyloides fusion also takes place high up-almost as soon as the pith is reached. The centripetal xylem of the twin bundles fuses in a definite manner (Scott, 1912, p. IOI9), and here also persists for a long way down, after fusion has taken place.

In $M$. multirame, on the other hand, the twin bundles remain distinct for a considerable distance at the edge of the pith. Thus in the case just considered, they are reaching the pith in one section, remain quite distinct through the next two, and only become united into a common mass in the fourth section. There is never in fact a definite fusion, such as we see so clearly in the other two species. The two bundles, together with the median strand, merely group themselves in one mass. The centripetal xylem has already ceased to be distinguishable before this grouping is accomplished. The resemblance to $M$. Sutcliffi is much closer (Maslen, 1911, p. 396, Pl. XXXIII, Figs. 3-5); in fact, there appears to be no essential difference in the behaviour of the leaf-traces of these two forms.

One or two other points connected with the course of the bundles may be noticed. I have tried to find out whether any regular order is followed in the subdivision (or fusion, according to the direction in which we follow them) of the bundles of the leaf-trace in the cortex. It will be seen in PI. XI, Fig. 3 that each of the two strands of the double trace is dividing unequally, the outer segment on either side being about twice as broad as the inner. If one follows the trace farther out, one finds, as would be expected, that the outer strand on either side divides again; this gives two groups of 3 bundles each, with a wide space between them. The next stage shows less constancy; sometimes the outermost bundle divides once more ; sometimes it is the innermost bundle of the 3 that divides; the two sides of the same trace may differ in this respect. In any case there are now 8 bundles, which seems to be the regular number entering the base of the leaf. No doubt further subdivisions then go on, as in $M$. Sutcliffii, in which Mr. Maslen observed 16 in a petiole (Maslen, 1911, p. 405). The whole process of subdivision of the trace agrees closely with that in $M$. Sutcliffi, and Mr. Maslen's figures illustrate the essential points sufficiently (l.c., Pl. XXXIV, Figs. 8-10). 
Another point is the relation of the axillary stele to the subtending leaf-trace. The stele as it passes in through the cortex and phloem makes an acute angle with the vertical, and consequently is cut almost transversely in transverse sections of the main stem. Immediately on reaching the secondary wood, however, its elements take an almost horizontal course, as shown in Pl. XI, Fig. 3. This is no doubt (like the corresponding curvature of the trace-bundles) an accommodation to the secondary growth of the main axis. As already mentioned, the wood of the axillary stele is connected on either side with the wood on its flanks; sometimes the stele is so much affected by these lateral connexions as to appear split into two lateral halves (cf. Maslen, 1911, p. 407).

Another interesting point is the relation of the axillary stele to the primary bundles of the main stem. This is difficult to make out in a stem which has already undergone a good deal of secondary growth. But, in favourable cases, strands of primary, spiral or scalariform, elements can be seen curving to the right and left at the inner end of the axillary stele, as if to join the adjacent leaf-trace bundles on either side (cf. Pl. XIII, Fig. I4). It appears, then, that the axillary stele in its vascular connexions follows the Coniferous type ; it is not directly connected with its own subtending trace, but with the trace-bundles to the right and left, between which its own trace passes out. The same relation was found by Bertrand and Renault in Poroxylon (1886, pp. 296, 300-3, Fig. I99), where the insertion of the axillary branch takes place on the two bundles which enclose between them the outgoing leaf-trace.

In tracing the connexions of the bundles I have, for obvious reasons, confined my attention to the xylem.

\section{The Axillary Shoots.}

The axillary shoots are a most characteristic feature of the species and suggested the choice of the specific name multirame. As already mentioned, every leaf, through a considerable length of stem, bears a shoot in its axil ; in the upper part of the specimen, however, these shoots are undeveloped.

The type-specimen only shows the bases of the axillary shoots. We find these well preserved up to the point where they are just free from the main stem; beyond that, except for some doubtful fragments, they cannot be recognized. The best section for them is 2335 , in which 3 are shown, which are nearly or quite free from the stem (see photograph, PI. XI, Fig. 2). The best preserved is shown in detail in Pl. XIII, Fig. 22. At this level the shoot is absolutely leafless; its outline is more or less elliptical, with the long axis tangential to the parent stem; the dimensions in this case are about $6 \times 3 \mathrm{~mm}$. The stele has the remarkably flattened form to which attention has already been called. Its dimensions are about $3.5 \mathrm{~mm}$. long by $0.3 \mathrm{~mm}$. broad. The detached portion at one end might be taken for 
a leaf-trace. Similar bodies are shown in two other cases, but it seems certain that their separation from the compressed stele is merely accidental.

The pith is here practically obliterated; in cases where it is rather better preserved 'secretory sacs' with black contents are evident. Centripetal wood has not been recognized, and it is very doubtful if it was present; the centrifugal wood has about five tracheides in each radial row. Where the section is oblique we find that the tracheides are scalariform or spiral, not pitted. The phloem-zone is ill-preserved. The cortex is on the whole of uniform parenchymatous structure, the cells becoming smaller towards the outside ; many elements with brown contents, perhaps secretory, are present. In the abaxial half of the shoot, tangential divisions have taken place, both in the inner and middle regions of the cortex. A small-celled epidermis can be traced in many places.

The flattened form of the stele is constant and evidently, in the main, natural, the other tissues showing no sign of compression or distortion. The pith is, however, somewhat more compressed than is natural, as shown by its better preservation in some sections than in others. This excessive compression may be due to growth of the cortical tissues of the shoot, indicated by the frequent occurrence of tangential divisions.

The axillary stele is a good deal better preserved where it has entered the cortex of the stem (Pl. XIII, Fig. 2I). Its sectional form is here no longer flattened, but simply elliptical, measuring, in the example figured, about $1.5 \times 0.75 \mathrm{~mm}$. This section is cut at the level where the axillary stele has just traversed the cortex and its pericycle is in contact with that of the stem. The pith shows some signs of compression, owing, no doubt, to the secondary growth of the stele in a confined space. Dark (secretory?) elements are present, as before. Groups of thick-walled elements at the inner edge of some of the xylem-wedges seem to represent the centripetal xylem, but I have not been able to determine the position of the protoxylem, so this interpretation is by no means secure. The centrifugal wood has a thickness here of $8-10$ elements. It is arranged in definite wedges, the medullary rays between them being broad, owing partly to the size and partly to the number of their cells; though most of the rays appear to be uniseriate, some are three cells wide.

The phloem-zone is well developed-quite half as thick as the wood; in this region the cells of the rays are often tangentially dilated. The zone, with numerous dark-brown elements, beyond the phloem may be regarded as pericycle, but is not well defined.

The axillary stele as it passes through the cortex has essentially the same structure in $M$. multirame as in $M$. Sutcliffii (cf. Pl. XIII, Fig. 2 I, with Maslen, 1911, Pl. XXXIV, Fig. II), though on a smaller scale in the latter species. The shoots, however, when they become free are totally different, the little leafy buds of $M$. Sutcliffii, with a cylindrical axis and cylindrical 
stele, contrasting strongly with the naked elliptical shoots of $M$. multirame with their remarkable flattened stele (cf. Pl. XIII, Fig. 22, with Maslen's Pl. XXXVI, Fig. 20). Of course this difference cannot be taken as a specific character; it is more likely that the distinction between the two kinds of axillary shoots depends on function ; the one, for example, may be vegetative, the other reproductive. There is some additional evidence, given below (p. 452), bearing on the function of the axillary shoots.

\section{The Wood and Phloem.}

The centripetal wood of the leaf-traces is shown in a bundle from the outer cortex (one of eight forming the trace) in Pl. XIII, Fig. I8, and in a double bundle at the margin of the pith in Fig. I9 (see also the photographic Pl. XI, Figs. 3, 4, and 5). In the type-specimen it is perhaps rather less developed than in $M$. poroxyloides. The parenchyma accompanying the protoxylem is present, but in transverse section is not always easily distinguishable from the xylem.(P1. XIII, Fig. 19).

The structure of the secondary wood may be said to be identical with that in $M$. poroxyloides; in particular, we find everywhere a considerable thickness of spiral and scalariform elements (not less than 6-8) before the typical pitted tracheides of the secondary wood begin. In this respect $M$. multirame agrees with $M$. poroxyloides and differs from $M$. Sutcliffi and M. Lomaxii, in which the non-pitted type of wood is nearly or quite limited to the neighbourhood of the leaf-traces. The pitted tracheides commonly have two rows of alternating pits on their radial walls--sometimes there is a single row only. The tracheides range from 24 to $36 \mu$ in diameter; the rays are narrower-about $\mathrm{I} 8-24 \mu$.

There is in some parts of the wood a large proportion of very low rays I-3 cells in height. Higher rays also occur, up to a height of I2-I 4 cells. Occasionally a ray-cell is found divided radially, making the ray biseriate at that point. The phloem and pericycle show no clear difference from those of $M$. poroxyloides. They are better preserved in another specimen. Immediately outside the pericycle a zone of periderm is already forming (Pl. XI, Fig. 4).

\section{The Cortex.}

The cortex, where completely preserved, is a broad zone $3-3.5 \mathrm{~mm}$. in width. Between the leaf-traces the greater part of this zone is taken up by the mechanical Dictyoxylon tissue, which is extremely well developed; only a narrow band of parenchyma intervenes between the pericycle and the beginning of the fibrous strands (Pl. XI, Figs. I and 2). But here, as in other species, the outgoing leaf-trace is accompanied by a mass of parenchyma, and at these places the Dictyoxylon zone is consequently much reduced in width (Figs. 2 and 3). The fibrous bands of the Dictyoxylon cortex often form a network as seen in transverse (Figs. 2 and 3 ) as well as in tangential 
section (Fig. 6). The tangential section shown photographically in Fig. 6, though imperfectly preserved, gives a good idea of the distribution of the leaf-bases, which are recognized at once by the parenchymatous masses traversed by the bundles of the trace; three such leaf-bases are shown; between them the plane of section passes through the Dictyoxylon cortex. In connexion with one leaf-base the axillary stele is shown. It will be noticed that the leaf-bases are moderately crowded, but so as to leave a quite appreciable cortical surface between them; here again the structure is much the same as in $M$. poroxyloides.

On the whole there seems to be scarcely any difference between these two species (apart from the probably accidental one of the presence or absence of axillary shoots) except in the mode of fusion of the leaf-trace bundles at the edge of the pith. This, however, is apparently important enough to justify keeping up the distinction.

The affinity to $M$. Sutcliffi is also very close; here the course of the bundles appears to be identical, and the chief distinction is found in the structure of the inner secondary wood, which in $M$. multirame everywhere has numerous layers of scalariform and spiral elements, while in M. Sutcliffii, 'with the possible exception of a very few elements on its inner edge, the whole of the secondary xylem-ring, apart from the leaf-traces, consists of pitted tracheides' (Maslen, 1911, p. 399).

\section{Other Specimens.}

A specimen received from $\mathrm{Mr}$. Lomax in $1912^{1}{ }^{1}$ requires some special notice as it is in most respects the best-preserved Mesoxylon yet discovered, and differs in certain points from the type. Like the latter it is a coal-ball specimen from Shore, Littleborough. A portion about $I \frac{1}{2}$ inches in length was cut into a series of 13 transverse sections (Nos. 2760-2772) and 8 longitudinal sections (Nos. $2773-2780$ ) were obtained from the rest of the fragment.

It is a relatively large stem, about $4.5 \mathrm{~cm}$. in diameter, if complete. The diameter of the pith is about $19 \mathrm{~mm}$, the thickness of the wood $7-7.5 \mathrm{~mm}$., that of the phloem and pericycle about $3 \mathrm{~mm}$. The cortex is less well preserved than the other tissues, but was apparently about $3 \mathrm{~mm}$. in thickness. The stem was thus a larger one to start with and also more advanced in growth than the type-specimen. The arrangement of the numerous leaf-traces is similar to that already described. As the stem is not quite complete, it was not possible to determine the phyllotaxis exactly; the divergence may have been either $\frac{8}{21}$ or, more probably, $\frac{13}{3} \frac{3}{4}$. The behaviour of the leaf-traces agrees with that in the type; the two bundles of the entering trace remain separate after entering the pith, and there is no

${ }_{1}^{1}$ Referred to a previous paper in connexion with $M$. poroxyloides (Seoit, 1912, p. $102 \mathrm{I}$ ). 
actual fusion. Axillary steles are present in connexion with some of the leaf-traces.

The points in which this specimen throws further light on the structure of the stem will now be indicated.

While the middle part of the pith has perished, only the outer ends of the diaphragms remaining, the persistent external zone is remarkably well preserved. The layers next the wood have somewhat smaller cells than the rest, usually with dark contents, perhaps indicating the presence of starch reserves during life (Pl. XII, Figs. I4, I 5). The persistent pith cells generally are isodiametric in transverse section, and appear somewhat flattened (broader than long) when cut longitudinally. There is little elongation even of the peripheral cells. In these respects the specimen differs somewhat from the type (see above, p. 439). The inner layers show evident tangential divisions, suggesting that a medullary periderm was being formed as a barrier towards the central cavity, which, apart from the diaphragms, must have existed during life. The same is the case where the continuity of the persistent zone is interrupted by a radial split. The frequent transverse splits in the persistent zone, however, show no sign of periderm formation, and were evidently due merely to post-mortem shrinkage, which may account in part for the flattened form of the cells.

The details of the course of the leaf-traces are shown even better than in the type-specimen. A typical leaf-trace, with its axillary stele, shows the following changes, followed from above downwards.

The trace chosen first appears in the second section, $276 \mathrm{I}$. Here two bundles (one of which is double) are seen somewhat obscurely in oblique section entering the periderm. In the wood opposite this point a double, nearly horizontal, strand is conspicuous, the two parts of the strand 0.4 to $0.45 \mathrm{~mm}$. apart. From evidence adduced below, there is no doubt that this represents the axillary stele of the trace, which is known to have often divided into two in its passage through the wood.

2762. Here the two bundles of the trace, about $1.5 \mathrm{~mm}$. apart, are seen clearly in transverse section in the periderm; one of them is still evidently double. The axillary stele, as such, has disappeared, having already fused with the wood, at this level; but its place is marked by a conspicuous bay in the inner edge of the wood, into which a median strand projects. This is always the indication of an axillary stele having just passed in.

2763 . The two bundles of the trace have reached the phloem, and are about I mm. apart; at the inner edge of the wood the bay, with the median strand, is very conspicuous.

2764. The trace has passed rapidly inwards and the two strands have now traversed the wood and reached the bay. This quick passage is of course due to the almost horizontal course taken by the trace through the 
secondary wood. Having reached the pith the strands turn down again and are cut almost transversely. They are converging somewhat, and between them, separated from each by a medullary ray, is the median strand, now a good deal narrower. The centripetal wood of the leaf-trace strands is well developed, and each is provided with a thick sheath of radially arranged elements, some of which are evidently tracheides. The median strand has no sheath and it is doubtful whether any of its xylem is centripetal, though in other cases it appears to be so.

2765. The two strands are now flush with the inner edge of the wood and are about the width of a strand apart. The median strand is much reduced.

2766. They are somewhat nearer together; the median strand has disappeared, the two leaf-trace strands are separated by a ray. with intercalated narrow radial bands of tracheides. The sheath has practically died out.

2767. The strands are here close together, but still quite distinct, with their centripetal wood still well developed.

2768. Little or no change. At this level the double trace still projects into a bay of the wood.

2769. The double trace is prominent, as before, while the two centripetal groups are still distinct, though reduced; the centrifugal part of the xylem is no longer in two parts, but consists of six or seven radial bands, one of which is median.

2770. The double trace is still slightly prominent with remains of the two centripetal groups: The centrifugal xylem is scarcely marked off from the rest of the secondary wood.

$277 \mathrm{I}$. The trace is no longer recognizable.

It will be seen, on comparing the description of the course of a leaf-trace in the type-specimen, that there is no essential difference. Here also there is never an actual fusion of the two strands; they merely become merged in the general zone of secondary wood; the centripetal xylem-groups persist and remain distinct as long as the trace retains its individuality. The sheath, only seen where the twin bundles first reach the pith, is better marked here than in the type. The leaf-traces are very numerous. In one transverse section (Pl. XII, Fig. I5) I 3 can be recognized in different parts of their course, and on following the series through the successive sections, many others make their appearance ; the total number found was 28 , but possibly they may not quite all represent distinct orthostichies. However, the actual number was undoubtedly greater, as the sections are incomplete. As already mentioned, the phyllotaxis, while not exactly determinable, was evidently a complex spiral, with a most probable divergence of $\frac{13}{3} \frac{3}{4}$.

The axillary steles are not well represented in the transverse sections; they are better developed in the part of the stem shown in the longitudinal sections, cut above the transverse series. The best of those in the trans- 
verse sections is shown in Pl. XIV, Fig. 23. It is a small strand, only about $0.7 \mathrm{~mm}$. in diameter; the phloem and cambium are well preserved; the wood is very parenchymatous, but tracheides extend to the centre of the stele. It is quite possible that this was a rudimentary or abortive stele, for those shown in the longitudinal sections are considerably larger, and have a definite pith.

The tangential sections show the changes in the axillary stele very clearly - one of these steles can be recognized in the phloem (section 2773); but it is in the wood that the preservation is best. In the outer zone of the wood (section 2774) an axillary stele (about $1 \mathrm{~mm} . \times \mathrm{I} \cdot 4 \mathrm{~mm}$. in diameter) is cut almost transversely; the pith is elliptical, with the major axis horizontal. The wood of the branch, mostly secondary, is chiefly developed on the lower side, when it passes over directly into the longitudinal strands of the stem-wood: the same is the case laterally, but on the upper side the transition is much more abrupt, the tracheides here running horizontally, often with upward bends. The subtending trace is not visible, though the wood is shown for about $4 \mathrm{~mm}$. below the stele.

In the next inner section $(2775 ; \mathrm{Pl}$. XII, Fig. I 2) an interesting change appears ; the axillary steel is deeply bilobed, a wedge-shaped incision, filled with stem-wood, extending almost half-way through it from the upper side. The lower and lateral connexions with the stem-wood are essentially the same as before; on the upper side the stem-tracheides converge, to enter the incision. About $4 \mathrm{~mm}$. below the stele the two strands of the subtending leaf-trace are present, though partly cut away; they are not included in the photograph.

The next section $(2776)$ passes in the middle part, through the persistent zone of the pith, showing the wood, in oblique section, on either side. In the wood, to the left, an axillary stele (not the same as in the preceding sections) is seen, quite in the inner part of its course (P1. XII, Fig. I3). The stele is here completely severed into two, the longitudinal stem-wood extending uninterruptedly between the two halves. The width of the gap, narrowest in the middle, varies from about 0.4 to $0.25 \mathrm{~mm}$. The half-steles here consist largely of pith. The wood is mostly limited to the upper and outer sides, and is everywhere in continuity with that of the main stem, the lateral connexions being the most extensive.

Thus the occurrence of a division of the axillary stele into two, where it approaches the primary wood of the stem, is demonstrated. The strand of stem-wood separating the two halves of the divided stele is no doubt continuous with the median strand observed in the transverse sections.

The division of the axillary stele is not, however, constant, as is shown by the transverse sections; of five clear cases observed in the series, the stele was divided in three and undivided in two. One of the latter is represented in P1. XII, Fig. 14. The stele abuts on a pith-bay and is clearly 
a single strand all through. The tissue in the middle of the stele is pith, and that at its sides wood. There are slight irregularities in the distribution of the tracheides, but no sign of stem-wood interrupting the continuity of the tissues of the axillary stele. The next section below shows a pith-bay and median strand, just as in other cases where a stele has entered.

It thus appears that the division of the axillary stele inwards is an inconstant character of little importance; only its connexions with the stemwood are essential. Very little is shown in this specimen of the axillary shoots when free from the stem. An example in the first section of the transverse series $(2760)$ has a flattened stele with little secondary wood, and appears to be similar to the shoots so well represented in the type.

One or two points may be mentioned in which this specimen supplements the results obtained from the investigation of the type, as regards zood and bast. The pitting on the radial walls of the cells of the rays is fairly shown in places. The number of pits in the 'field' (i.e. in the area where a ray-cell crosses a single tracheide) is from three to six ; these pits are elliptical, often oblique, and appear to be simple (Pl. XIV, Fig. ${ }_{25}, m . r$. .).

A point of interest is the presence of pits on the tangential walls of some of the tracheides, especially as the occurrence of tangential pits in Palaeozoic woods has recently been denied (Jeffrey, 1917, p. 49). They are clearly shown in Pl. XIV, Fig. 24, from a tangential section through the outer part of the wood. Sometimes they form a single row, sometimes two or more ; in the latter case they are sometimes very oblique. They are only to be found on a few tracheides, as is shown in transverse sections where the pitting can be distinguished with sufficient clearness to show its distribution.

Tangential pits in Pitys antiqua were described and figured in 1902 (Scott, 1902, p. 352, Pl. VI, Fig. 20), but do not seem to have been often met with as yet in wood of Palaeozoic age.

Another feature shown in the specimen under consideration is the presence of wood-parenchyma, which appears at several places. The strand shown in Fig. 25 lies at a distance of about $3 \mathrm{~mm}$. from the pith. It consists of a long vertical row, in part double, of cells with transverse walls. Their length here ranges from about 100 to $200 \mu$, with a width of $36-48 \mu$. Where the diameter appears about twice as great $(84 \mu)$ it is possible that longitudinal walls may have broken down. Many of the cells have dark, perhaps resinous contents. Similar rows of cells occur at other places farther out in the wood. Sometimes the individual cells reach a length of about $430 \mu$. The cell-walls are rather thinner than those of the tracheides, and appear to be without pits. In some places there is a direct relation to the medullary rays; in one case a vertical strand extends from one ray to another, and appears to cross a third ray on the way. It may be asked whether the parenchyma may not be traumatic; there is apparent evidence of injury in the outer tissues of the stem, for at one place a layer of periderm 
cuts deeply into the phloem, enclosing disorganized tissue which had probably died off while the tree was living. There is, however, nothing to show that the wood was affected-it appears quite normal throughout. There are one or two black cracks, filled perhaps with an exudation of resin, but we have no reason to suppose that these lesions occurred during life.

I have observed what appears to be wood-parenchyma in another specimen (section 2578), but the evidence is not so convincing as in the cases just described. The presence of parenchyma in Cordaitean wood is exceptional. I have recorded its occurrence in a remote member of the Cordaitales, Pitys antiqua (Scott, 1902, p. 352).

The cambium is preserved in places, but the cells are usually somewhat collapsed. The same applies, to a certain

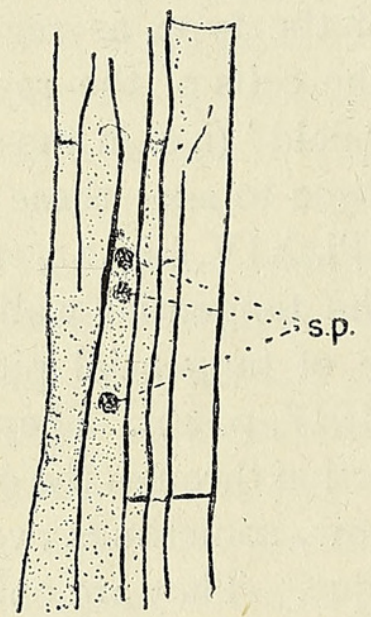

Text-Fig. I. From a radial section of the phloem, showing sieve-tubes and parenchyma. s.p., three sieve-plates on radial wall of a sieve-tube. $\times$ about $10_{5}$. R. S.

S. 2780 . extent, to the inner layers of the phloem, but the bulk of this tissue is extremely well preserved.

In transverse section the phloem (about $2 \mathrm{~mm}$. in thickness) is seen to consist of roughly tangentia! bands of larger and smaller elements (Pl. XI, Figs. 7 and 8). The former are $50-70 \mu$ in diameter, and are usually almost filled by a brown mass, either solid or with a small central lumen, and somewhat retracted from the cell-wall. In transverse section one might take this mass for thickened cell-wall in an altered condition, but in longitudinal section (Pl. XII, Figs. IO and II) it is evident that the brown substance is of the nature of cell-contents; it is irregularly broken up and resembles the supposed resin-masses often met with in the tracheides or wood-parenchyma. Transverse walls are seldom seen; they may sometimes be hidden by the dark contents, or may have broken down as Bertrand and Renault (1886, p. 292) found in the case of Poroxylon.

The smaller elements usually appear clear (Pl. XI, Fig. 8, and Pl. XII, Fig. II) ; sometimes they have quite light brown contents, and occasionally they may be infiltrated with the darker substance found in the long tubes. They are often flattened tangentially like cambial cells; the tangential diameter ranges from 50 to $24 \mu$, and the radial from 30 to $12 \mu$. They have often, as is obvious from the measurements, undergone additional radial divisions.

In longitudinal section it is found that these smaller phloem elements are of two kinds ; many of them have very distinct and frequent transverse walls; others are long and tapering and not septate (Pl. XII, Fig. II). The former must be regarded as phloem-parenchyma, the latter as sievetubes. It is very rare to find the sieve-plates preserved; but in the case 
figured (Text-fig. I) there are three areas on the radial wall of a tapering element, which show little bright dots on a light-brown background, and appear clearly to be lateral sieve-plates. Further, in a tangential section, the long oblique wall between two such elements shows, in sectional view, a number of thin places marked out in brown, which are no doubt the sections of sieve-plates or fields (Text-fig. 2).

In the outer part of the phloem the parenchyma consists of shorter and wider cells than elsewhere, reaching $60 \mu$ in diameter, with a length of $170-48 \mu$ (Pl. XII, Figs. 9 and IO). In the same region, elements have been observed with a thick spiral band; whether they were sieve-tubes or not cannot be as. certained. There was evidently some thickening or deposit on the walls, which became drawn out during growth into a spiral form; similar cases have been observed in the phloem of recent Ferns.

We may distinguish, then, three kinds of elements in the phloem-the long, perhaps resiniferous tubes, the sieve-tubes, and the phloem-parenchyma. There remain the phloemrays. In the outer part of their course they are appreciably dilated-2-3 cells wide, with the cells themselves much enlarged (Pl. XII, Fig. 9). They sometimes have brown contents, like those of the long tubes. Where the phloem abuts on the pericycle, much broader rays are often met with; these are probably principal rays, lying between the groups of primary phloem. The latter are

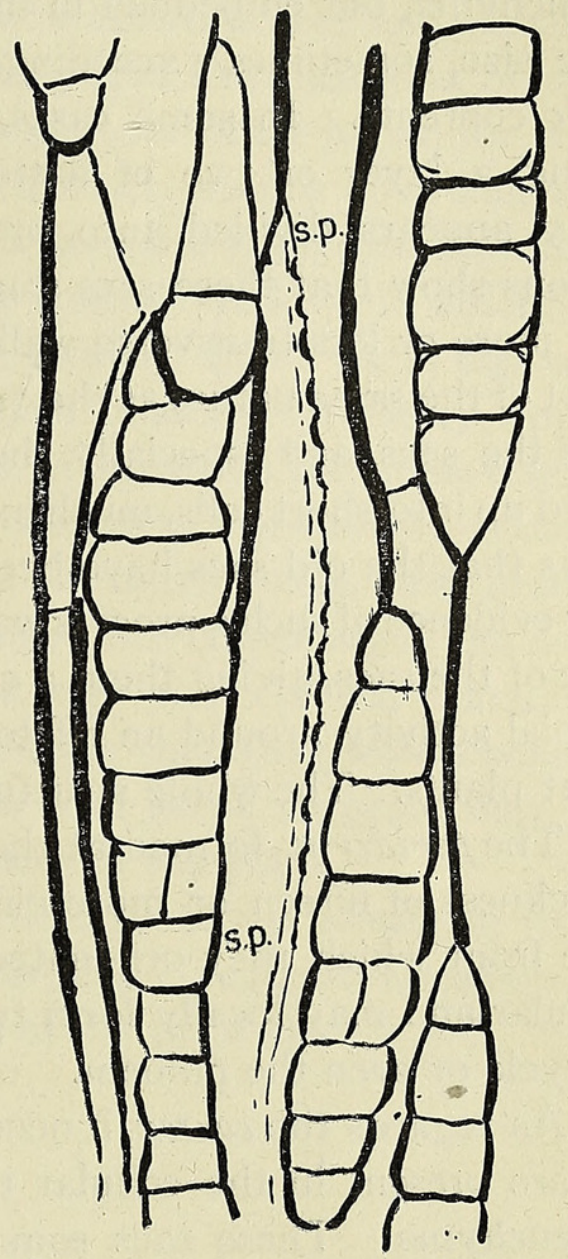

TEXT-FIG. 2. From a tangential section of the phloem, showing sieve-tubes, parenchyma, and rays. s.p.-s.p., wall of a sieve. tube, showing numerous sieve-plates in section. $x$ about 150 . R. S. S. 2773 . difficult to recognize in transverse section. A slight bulge in the outer margin of the phloem can sometimes be recognized opposite a primary xylem-strand, and occasionally a little group or band of rather thick-walled elements is seen in this position, perhaps representing the altered sievetubes of the primary phloem.

The general structure of the phloem of Mesoxylon multirame agrees very nearly with that of $M$. Sutcliffi, as described by Mr. Maslen (Maslen, 1911, p. 4co). The phloem of M. Lomaxii and M.poroxyloides is evidently very similar, though the preservation in the observed specimens is not so 
favourable as in the present case. On the other hand, the arrangement of the phloem elements in our plant is much less regular than that in Poroxylon (Bertrand and Renault, 1886, p. 288), and the supposed resiniferous elements are a much more constant and conspicuous feature.

The pericycle (about I $\mathrm{mm}$. in average width, but varying considerably) is distinguished at once from the phloem by the irregular arrangement and larger size of the cells (Pl. XII, Fig. 9). The matrix is formed of short-celled parenchyma, but embedded in this are very numerous and peculiar sacs, of large size, sometimes exceeding $200 \mu$ in diameter (Fig. 9), with brown or black contents. In some cases, but not very often, they resemble canals, having a layer or two of flattened cells around the cavity. Often the cavity appears divided into or filled by large cells. The longitudinal sections show that these sacs sometimes consist of a single row of elements, with more or less transverse walls and dark-brown contents. These are no doubt of the same nature as the 'resiniferous' tubes of the phloem. In other cases the sacs, and especially the largest of them, appear irregularly partitioned up into short cells, much exceeding those of the parenchyma in size. It seems that the old sacs have been obliterated, perhaps by tylosis, though no clear evidence of such a process was obtained. The flattened cells surrounding some of the sacs, giving them a canal-like appearance, may be due to a local cambial activity around an effete organ, such as has often been observed in recent plants. The whole structure of these sacs suggests a state of senility.

The periderm, formed at the outer border of the pericycle, has reached a thickness of fifteen or more elements. The cells, like those of the pericycle from which they originated, are short. The zone is in places very irregular and may locally form two bands, the inner cutting deeply into the pericycle or even the phloem.

As regards the cortex, it need only be said that numerous 'resiniferous' sacs are present in the cellular tissue, and often extend into the bands of sclerenchyma. These sacs sometimes appear septate, but in other cases they are continuous for long distances, perhaps partaking of the nature of the fibres with which they are associated.

From the description of this fine specimen it is evident that the plant must be referred to the species $M$. multirame, for it only differs from the type in quite minor characters. The specimen has been thought worthy of full consideration, as the excellent preservation exhibits in the clearest way the characters of the species and genus.

\section{A Possible Fructification.}

Of the remaining specimens referable to the species $M$. multirame, the only one which requires special notice here is a small stem, $2 \mathrm{~cm}$. in diameter, with the wood about $2 \mathrm{~mm}$. thick. ${ }^{1}$ It bore a number of axillary

1 Sections $25^{6} 3^{-2} 578$ in my collection. 
shoots, recognizable by their steles, which entirely agree with those of the type. But the particular interest of the specimen lies in the presence of a detached axillary shoot, clearly of the same nature as the others, and itself branched. This shoot is intimately associated with seeds, apparently identical with Mitrospermum compressum, A. Arber.

Mr. Lomax has long been convinced that this seed belongs to a Mesoxylon, and I am inclined to agree with him, but at present the evidence is not conclusive, for no case of actual connexion between seed and shoot has yet been met with. The subject of the supposed fructifications, of which there are several specimens, must be postponed to another paper, for not all of them appear to belong to the species with which we are now concerned. One point, however, may be emphasized. It is now certain that the axillary shoots of $M T$. multirame were branches of a special kind, quite different in their characters from the parent axis. The axillary shoot itself, characterized by its peculiar flattened stele and marked bilateral symmetry, appears to have been naked ; there is no clear proof at present that it bore leaves. It branched, however, repeatedly ; its branches were distichously arranged, their insertions lying in the principal plane of the narrow stele. The branches bore numerous scale-leaves or bracts, and also other appendages, the nature of which will be discussed elsewhere. The highly specialized character of the axillary branch-systems renders it probable that they were connected with reproduction, and the close association with seeds suggests that they may have constituted the female inflorescences of the plant.

There is evidence from a large specimen, probably belonging to this species, that the stem also branched in an ordinary vegetative manner, the branch in this case repeating the characters of the main axis.

\section{SUMMARY.}

The summing up of the main characters of the species may take the form of an amended diagnosis :

Mesoxylon multirame, Scott and Maslen, 1910.

Leaf-bases moderately crowded, not quite covering the surface of the stem.

Pith large, discoid, with a persistent outer zone.

Twin bundles of the trace remaining distinct for several internodes after reaching the pith, and never definitely fusing before they become merged in the woody zone. Trace dividing into eight bundles in the cortex.

Centripetal xylem persisting about as long as the two strands remain distinct. Sheath variable, limited to the region where the strands first reach the pith.

Tracheides of the whole of the inner part of the wood spiral, reticulate, 
or scalariform. Bordered pits in the rest of the wood usually in two rows. Tangential pits present in places.

Medullary rays $\mathrm{I}-\mathrm{I} 2$ cells in height, usually uniseriate. Ray-cells pitted on radial walls. Xylem-parenchyma occasionally present.

Phloem consisting of resiniferous (?) tubes, parenchyma, and sieve-tubes. Phloem-rays dilated.

An axillary shoot present in many of the leaf-axils. Shoot leafless, with a flattened stele, branching distichously, the branches bearing scaleleaves or bracts.

Seam-nodules, Shore, Littleborough. Lower Coal Measures.

It will be noticed that this diagnosis differs in several respects from the one originally given (Scott and Maslen, 1910, p. 238). It has been somewhat expanded as regards the leaf-traces, the wood, the phloem, and the axillary shoots. On the other hand, the cortical characters have been left out, as they seem to afford no real distinction.

The only really important differences from $M$. poroxyloides are in the course of the leaf-traces in the wood and in the axillary steles. The former is a definite and presumably constant distinction; the latter is probably more of biological than taxonomic significance. When we know $M$. poroxyloides better, we shall no doubt find that it sometimes produced some form of axillary shoot, and we have seen that such shoots are not everywhere present in $M$. multirame. As already stated, it is highly probable that the type of axillary shoot characteristic of this species was connected with reproduction.

From $M$. Lomaxii the distinctions are obvious, both in the course of the bundles and the structure of the inner part of the wood.

The latter character also distinguishes $M$. multirame from $M$. Sutcliffi, which further differs widely in the nature of the axillary shoots. This, however, as already pointed out, may be a matter of function rather than of specific distinction.

In the new diagnosis the comparison of the axillary shoot with a phylloclade is omitted, as it might be misleading, now that we know that the shoot represented a branch-system.

The points of more general interest are: The presence of tangential pits on some of the tracheides; the occasional presence of xylem-parenchyma; the structure of the phloem, consisting of more or less concentric bands of secretory sacs (probably resiniferous), sieve-tubes, and parenchyma; the lateral connexions of the axillary stele and its frequent division into two in passing inwards through the wood; the distichous branching of the axillary shoots, the branches bearing scale-leaves or bracts, and also, possibly, secondary branches.

On the whole the characters observed in this species accentuate the relation of the genus Mesoxylon to Cordaites (Renault, 1879, 1896), but it is 
very desirable that more detailed information as to the organization of the stem in the latter genus should be acquired, especially as regards the phloem.

It is hoped soon to publish a full account of the supposed reproductive shoots of the genus Mesoxylon and of the anatomy of the isolated species $M$. platypodium.

The photographs in Plates XI and XII are the work of Mr. W. Tams, while the figures in Plates XIII and XIV are from the hands of Mr. G. T. Gwilliam, Miss G. C. Harrison, and in the case of Pl. XIII, Fig. 2I, of Mr. J. Allen. The text-figures I and 2 were drawn by Mrs. D. H. Scott, F.L.S. To all these collaborators I am much indebted for their indispensable assistance.

\section{BIBLIOGRAPHY.}

1. Arber, A. (1910): On the Structure of the Palaeozoic Seed Milrospermum compressum (Will.). Ann. Bot, vol. xxiv, I9I0, p. 49 I.

2. Bertrand, C. E., et Renault, B. (1886): Recherches sur les Poroxylons, gymnospermes fossiles des terrains houillers stupérieurs. Arch. Bot. du Nord de la France, vol. ii, 1886, p. 243.

3. Jefrerey, E. C. (1917) : The Anatomy of Woody Plants. University of Chicago Press, 191\%.

4. MAslen, A. J. (1911): The Structure of Mesoxylon Sirtcliffii (Scott). Ann. Bot., vol. xxv, I9II, p. $38 \mathrm{I}$.

5. Renault, B. (1879): Structure comparée de quelques tiges de la Flore Carbonifère. Nouvelles Archives du Muséum, ii, $2^{\theta}$ sér., I 879, p. 2 I 3.

6. $(1896)$ : Bassin houiller et permien d'Autun et d'Épinac: Flore fossile. Étude des gîtes minéraux de la France, 1896 (Atlas, I893).

7. ScotT, D. H. (1902): On the Primary Structure of certain Palaeozoic Stems with the Dadoxylon Type of Wood. Trans. Roy. Soc., Edinburgh, vol. xl, Part II, 1902, p. 331.

8. (1912): The Structure of Mesoxylon Lomaxii and M.poroxyloides. Ann. Bot., vol. xxvi, 19.1 2, p. IOII.

9. - and Maslen, A. J. (1910): On Mesoxylon, a new Genus of Cordaitales. Preliminary Note. Ann. Bot., vol. xxiv, 1910, p. 236. 


\title{
EXPLANATION OF PLATES XI-XIV.
}

\author{
Illustrating Dr. Scott's paper on the Structure of Mesoxylon multirame.
}

The photographic figures require to be examined with a lens.

\section{PLATE XI.}

Photographs by Mr. W. Tams.

Figs. I-6. Type.

Fig. I. General transverse section of stem. An axillary stele is seen on the left. $\times 3 \frac{1}{2}$. S. 2338 .

Fig. 2. Half of a transverse section of stem, showing three axillary shoots, one above (see Fig. 22), one to the right, and one to the left, the two latter still connected with the cortex. $x$ slightly over $3 \frac{1}{2}$. S. 2335 .

Fig. 3. Part of transverse section, showing a divided leaf-trace in cortex, the whole thickness of which is shown, as well as the phloem and wood; the axillary stele is passing through the wood. $\times$ I3. S. 2342 .

Fig. 4. Double leaf-trace (No. 14 ) in pericycle. $x$ about 30. S. 2337.

Fig. 5. Transverse section of pith, wood, and phloem, showing a double leaf-trace in a pithbay. The centripetal xylem of the two strands is clear. $x$ about 30. S. $234 \mathrm{I}$.

Fig. 6. Tangential section, passing through three leaf-bases, with the Dictyoxylon cortex hetween them. In each leaf-base the bundles of the trace are seen. a.s. axillary stele, cut obliquely. $\times 3 \frac{1}{2}$. S. 2344 .

\section{Figs. 7, 8. Second Specimen.}

Fig. 7. Transverse section of whole thickness of phloem, with part of wood. On the right the large sacs of the pericycle are seen. $\times 30$. S. 2769 .

Fig. 8. Part of phloem more magnified, showing resiniferous(?) tubes, sieve-tubes, and parenchyma, and phloem-rays, with pericyclic sacs to right. $\times$ about 75. S. 2769.

\section{PLATE XII.}

Photographs by Mr. W. Tams.

\section{Second Specimen.}

Fig. 9. Transverse section of outer part of phloem (to left), pericycle, and part of periderm. The large, more or less obliterated, sacs of the pericycle are evident. $\times$ about 75 . S. 2769 .

Fig. 10. Radial section of the whole thickness of the phloem, with part of wood to left. On the extreme right pericyclic sacs are seen. $x$ about $30 . \quad$ S. 2778.

Fig. II. Radial section of part of phloem, more magnified. Here the pericycle is to the left. s. resiniferous (?) sacs; $\not$. phloem-parenchyma; s.t. sieve-tubes ; $r$. phloem-ray. $x$ about 75 . S. 2778 .

Fig. I2. Tangential section through the middle of the wood, showing an axillary stele beginning to divide into two. $x$ about 18 . S. 2775 .

Fig. I3. Approximately tangential section through the inner part of the wood, showing an axillary stele completely divided into two. $x$ about $\mathbf{5}_{5}$. S. 2776 .

Fig. 14. Transverse section, showing an undivided axillary stele (belonging to trace I2) passing horizontally through the wood, and abutting on a pith-bay. $\times$ about 25 . S. 2760 .

Fig. I 5. General transverse sections, showing leaf-traces, numbered I-I 3, from within outwards (not in order of phyllotaxis, as some are missing). 9, double trace passing through wood; 10 , pithbay with median strand; II, I2, I3, axillary steles entering through wood. Outside No. I I the bundles of the subtending trace are seen in the cortex. $\times$ slightly over $3 . \quad$ S. $2 ; 60$. 


\section{PLATE XIII.}

Drawings. Figs. I6, I 7 , and 22 by Mr. G. T. Gwilliam; Figs. I8-20 by Miss G. C. Harrison; Fig. 2 I by Mr. J. Allen.

Type.

Fig. 16. Somewhat diagrammatic transverse section of the stem. 3-16, leaf-traces, or (12-16) their axillary steles, numbered from within outwards. In trace 13 the subtending bundles are seen. ?, a doubtful auxillary stele. Traces I and 2 had already disappeared at this level and trace 15 is lost. $\times$ 4. S. 2334.

Fig. I 7. Radial section. c. cortex with leaf-trace; $x$. wood; p. discoid pith. $\quad \times 3 . \quad$ S. 2359 (probably from another fragment of the type-specimen).

Fig. 18. Leaf-trace bundle in cortex (one of eight in trace 7 ). $p x$. protoxylem; $x$. centripetal, $x 2$. centrifugal xylem; ph. phloem. $\times 165$. S. $233 \mathrm{I}$.

Fig. I9. Double leaf-trace (No. I2) at border of pith. $p x$. protoxylem; $x$. centripetal, $x 2$. centrifugal xylem; n.r. medullary ray. $\times$ about I IO. S. 2339.

Fig. 20. Leaf-trace cut lower down in its course. $p x$. protoxylem, here endarch; $x 2$. secondary wood; m.r. medullary ray. $x$ about I IO. S. 2339.

Fig. 21. Axillary stele in the cortex of stem. $x$. centripetal (?) wood; $x 2$. secondary wood; ph. phloem. The lower side is towards the axis. $x$ about 6o. S. 2339.

Fig. 22. Axillary shoot (No. 16) transverse, with the adjacent cortex of the stem. This is the uppermost shoot shown in Fig. 2. d.c. Dictyoxylon cortex of stem; st. stele of shoot. $\times 17$. S. 2335 .

\section{PLATE XIV.}

Drawings by Mr. G. T. Gwilliam.

Second Specimen.

Fig. 23. Sinall axillary stele in pericycle of stem; the wood extends to the centre. ph. phloem. The lower side is towards the axis. $x$ about 90. S. 2765 .

Fig. 24. Tangential section of wood, showing medullary rays and tangential pitting. t.p. two tracheides with one or more rows of pits on their tangential walls. $\times 200$. S. 27?4.

Fig. 25. Radial section of wood, showing pitted tracheides, medullary rays, and xylemparenchyma. x.p. xylem-parenchyma, the cells in $\mathrm{I}-2$ rows. m.r. medullary ray, showing pitting on the radial cell-walls. $x$ about 100 . S. 2780 . 

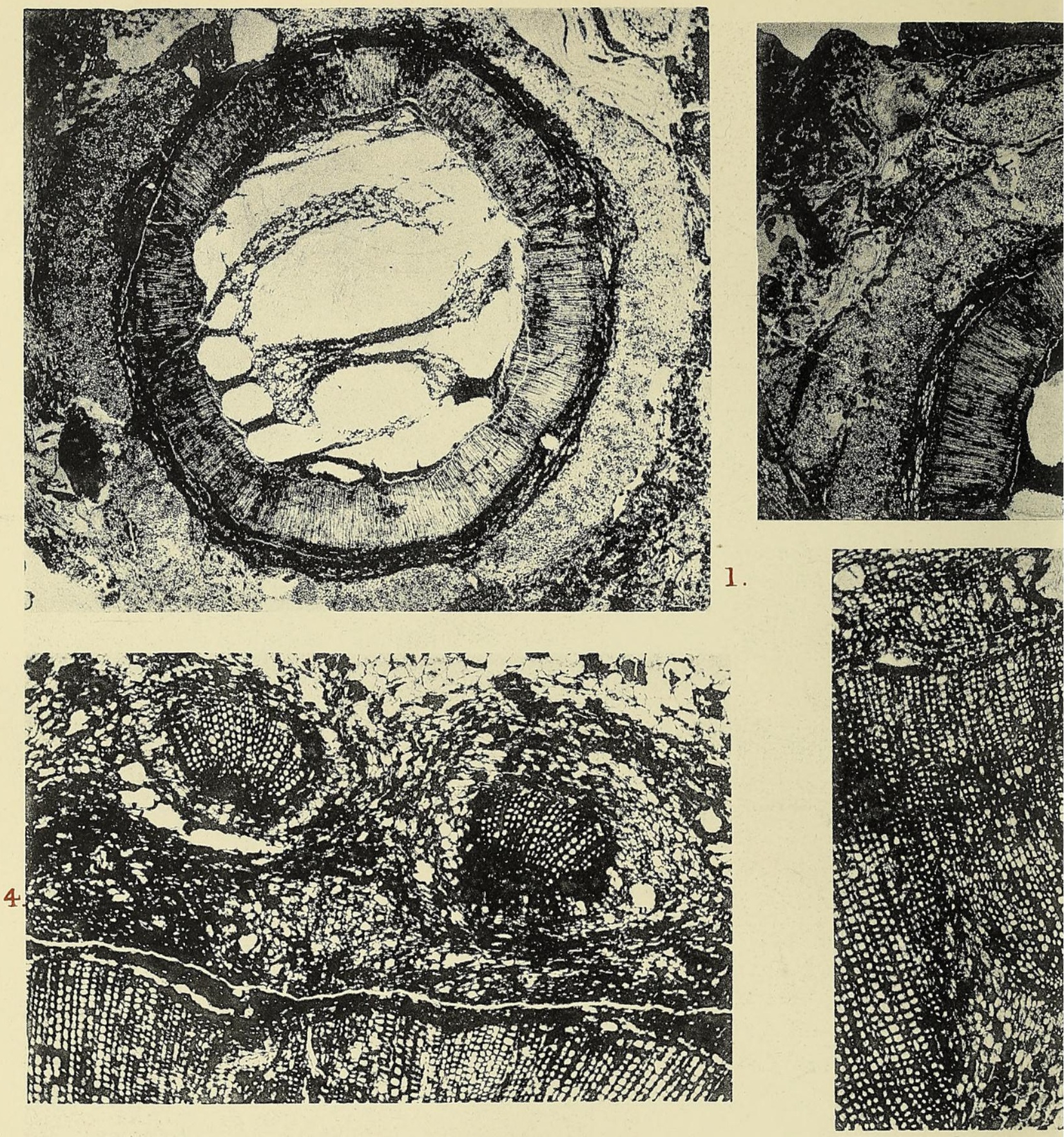

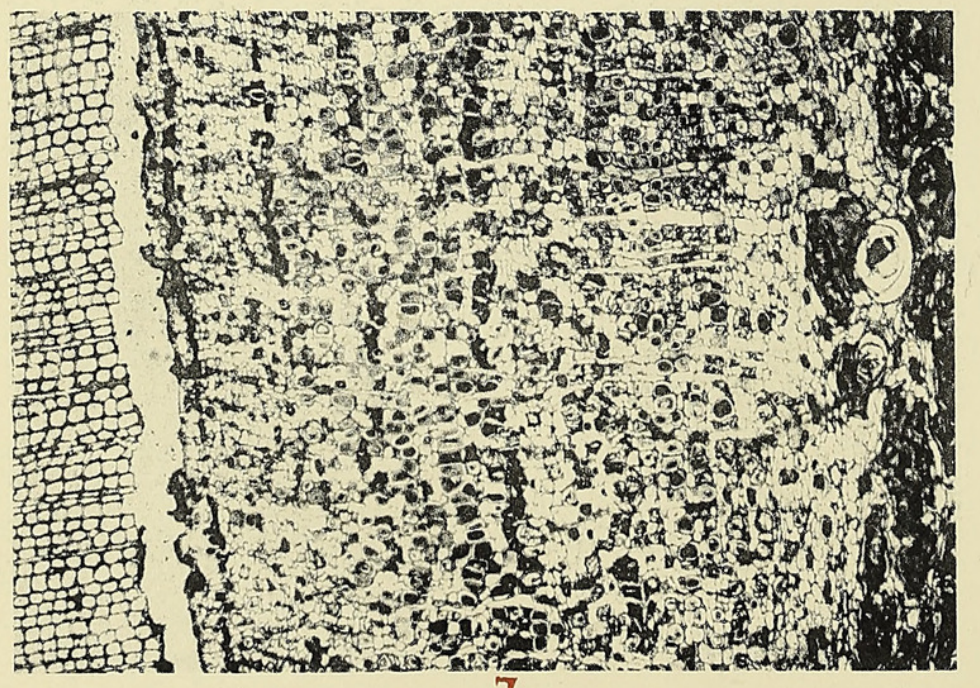

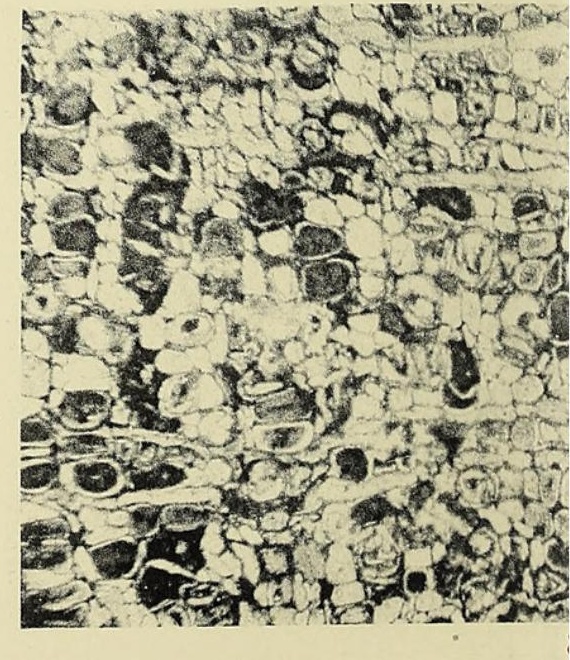



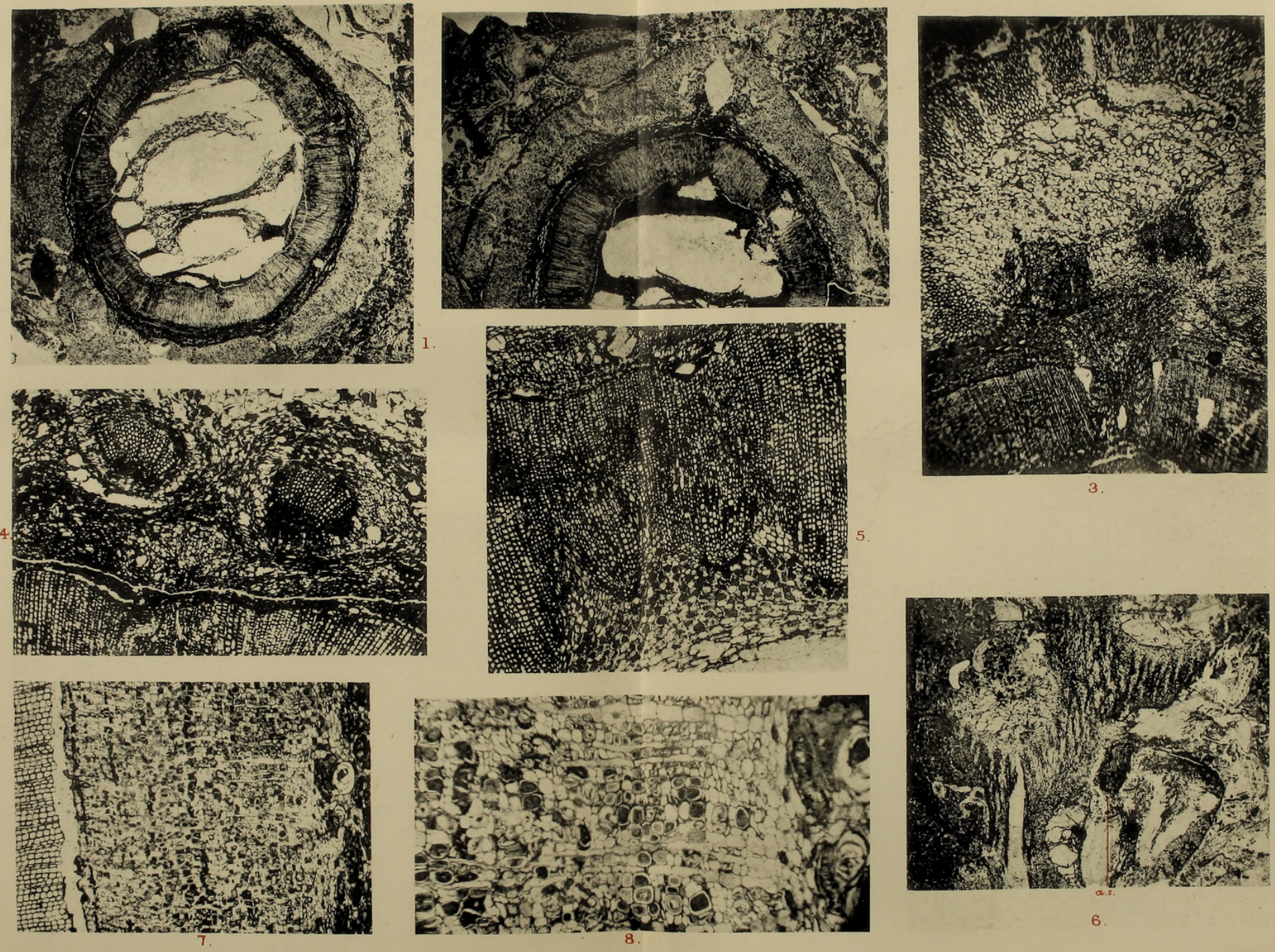
Annals of Botany,
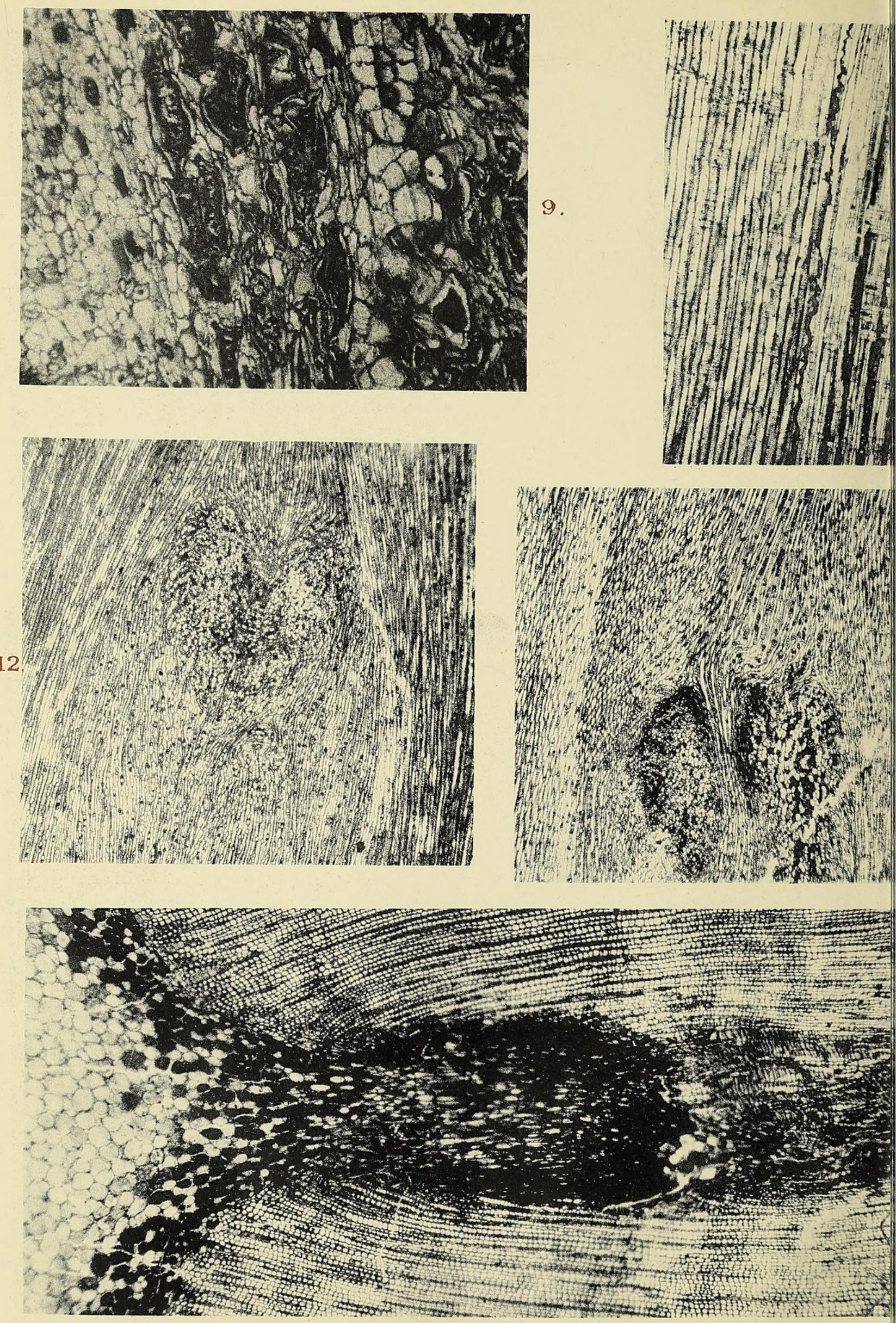


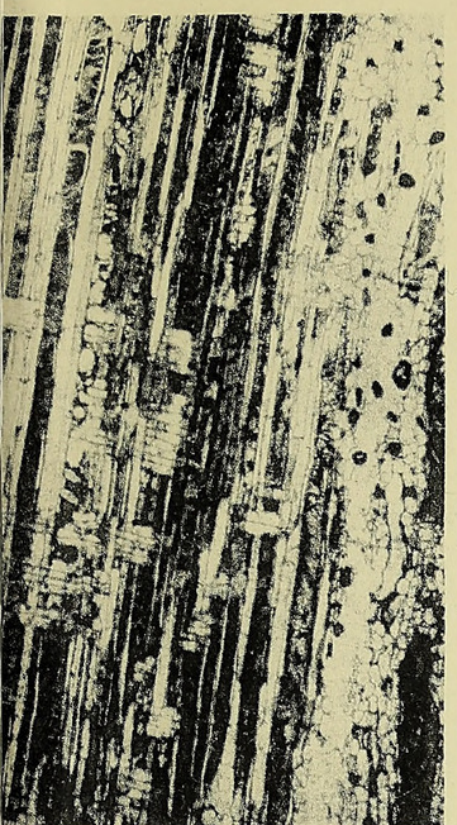

(5)

4.

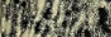

619

1) 2

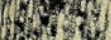

(2)

$y^{2}$

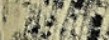

97

19.

1.

inily)

(a) 1

DIN

HW:

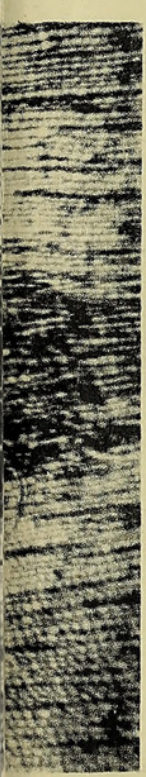

10.

13

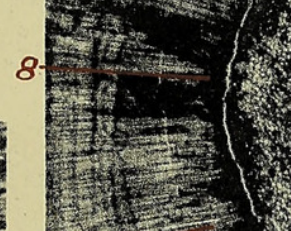

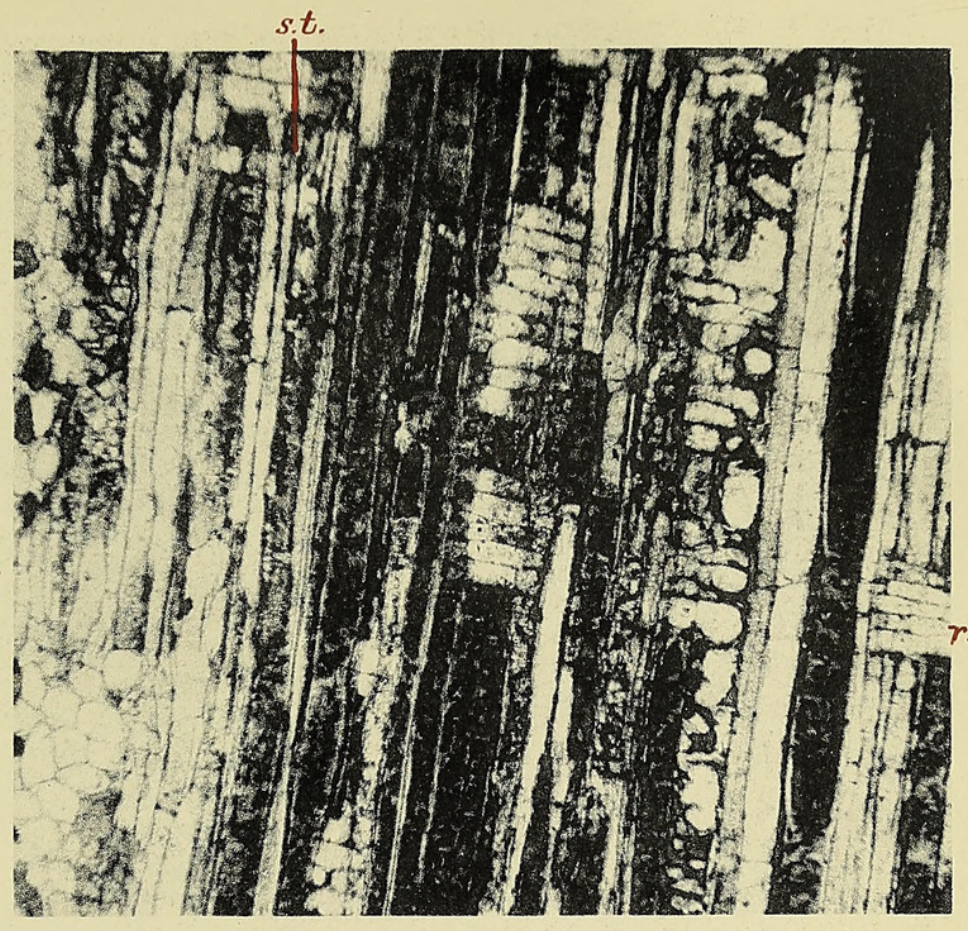

11.
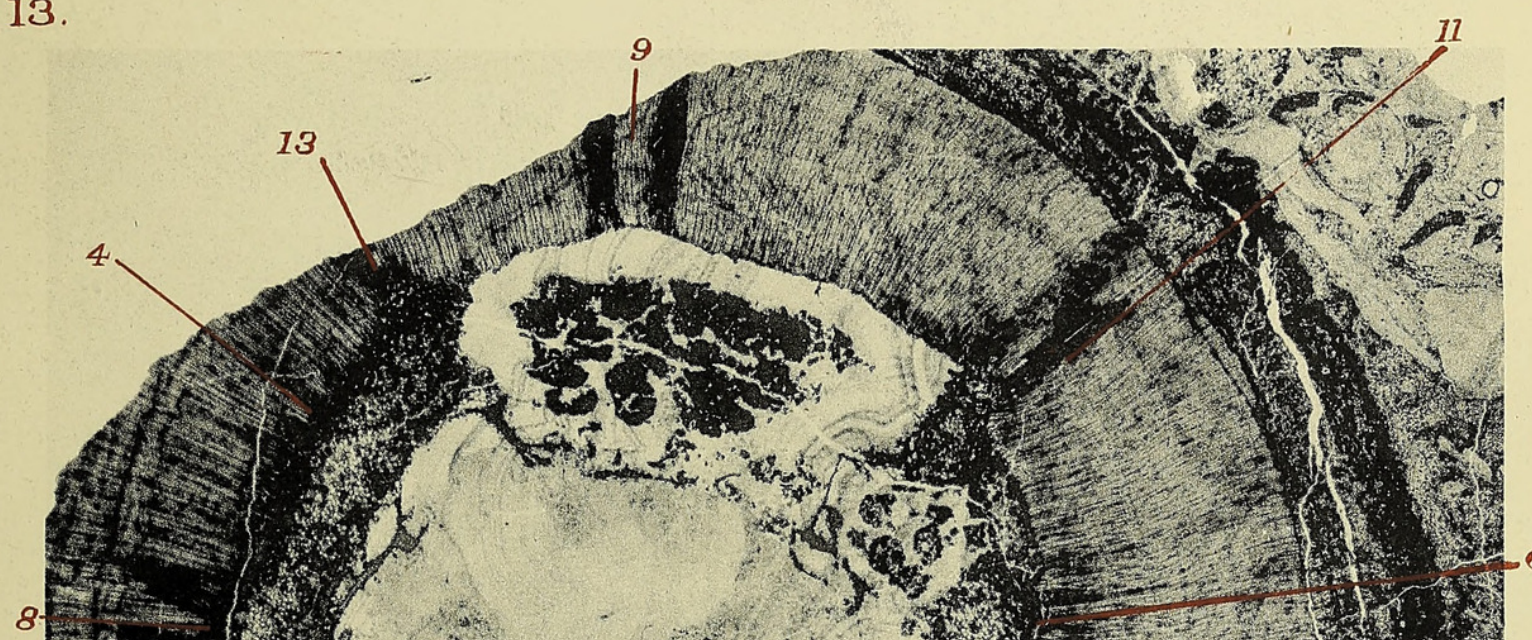
Annals of Botany

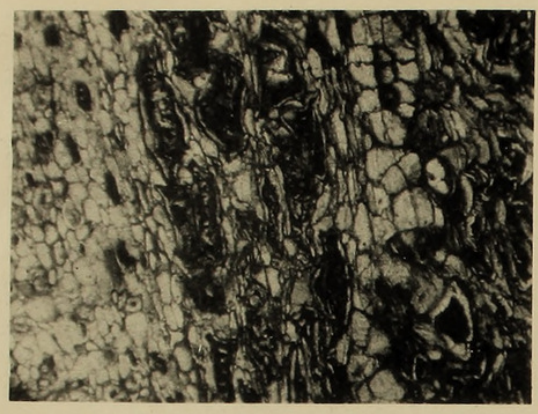

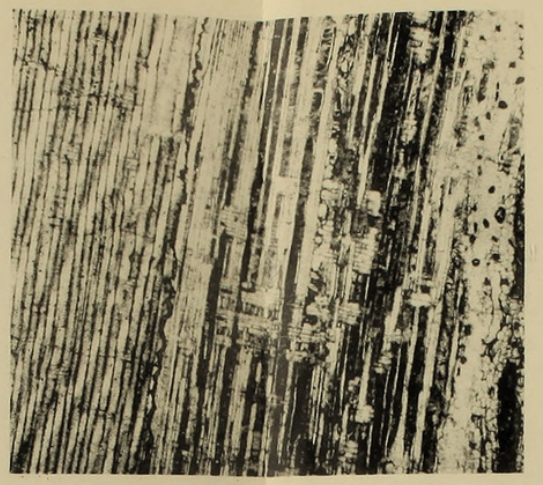

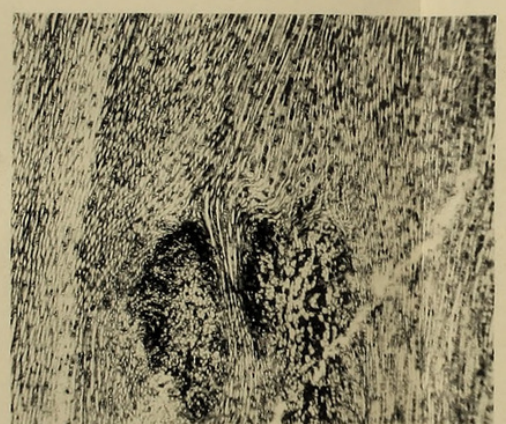

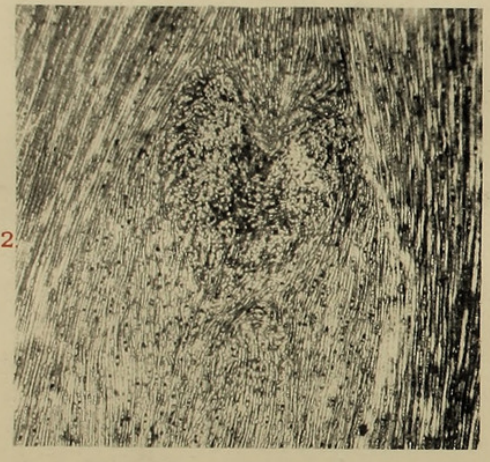

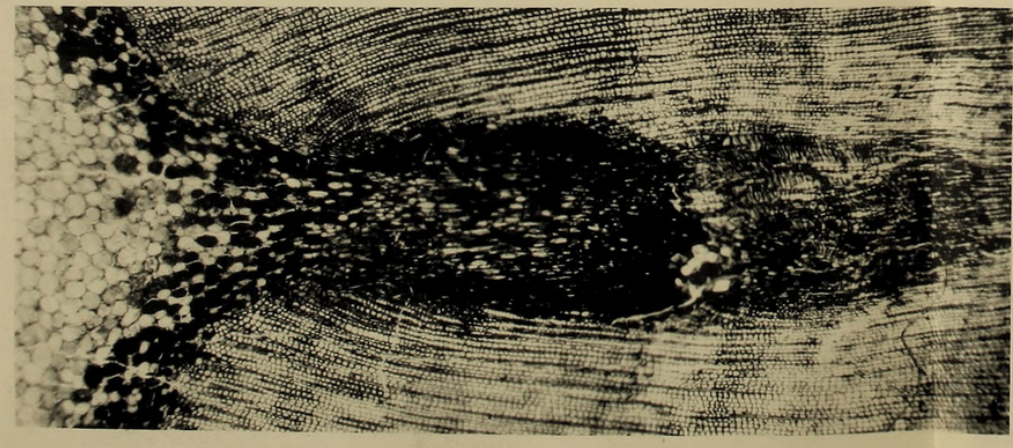

14

SCOTT-MESOXYLON
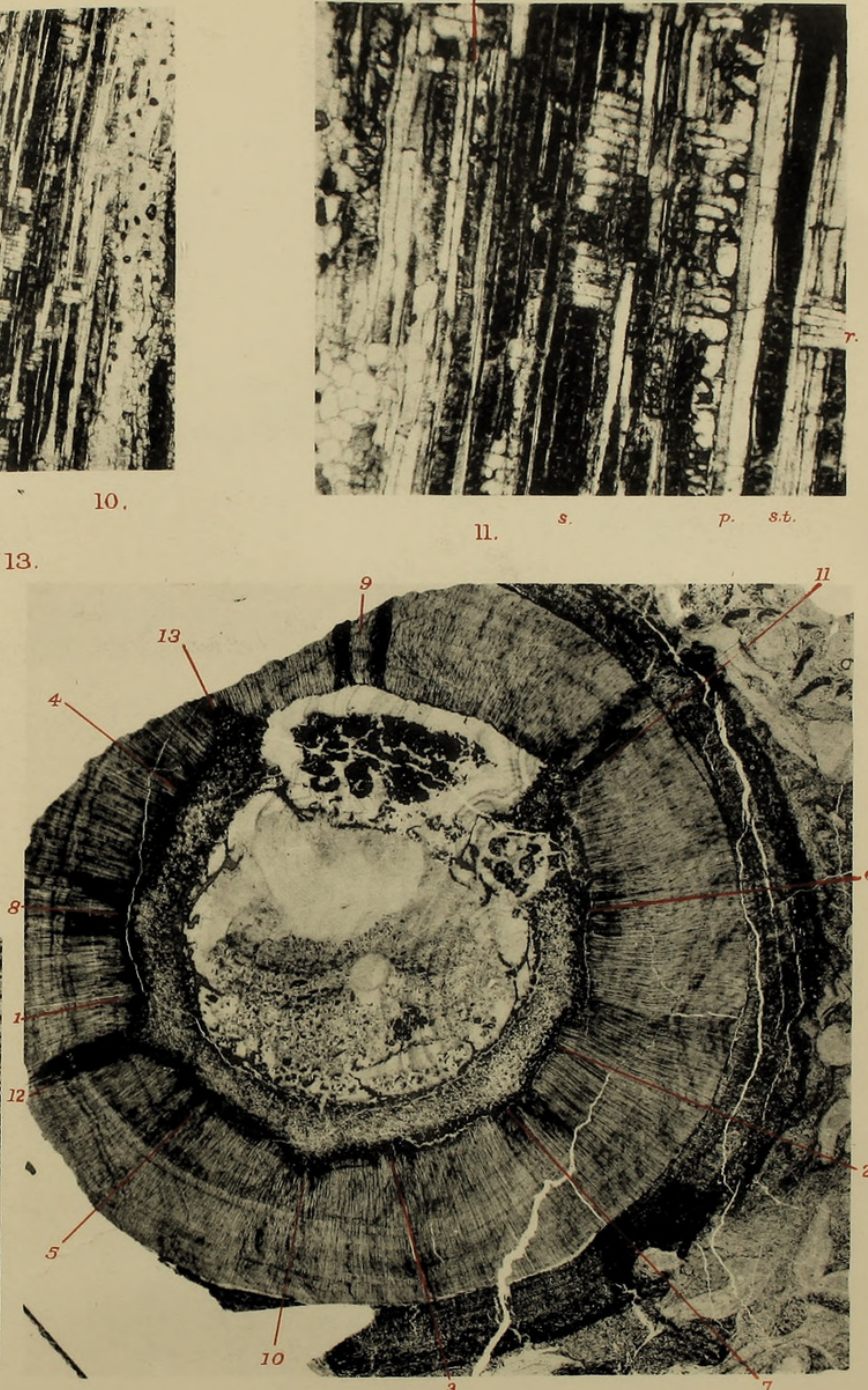

15 
Annals of Botany,
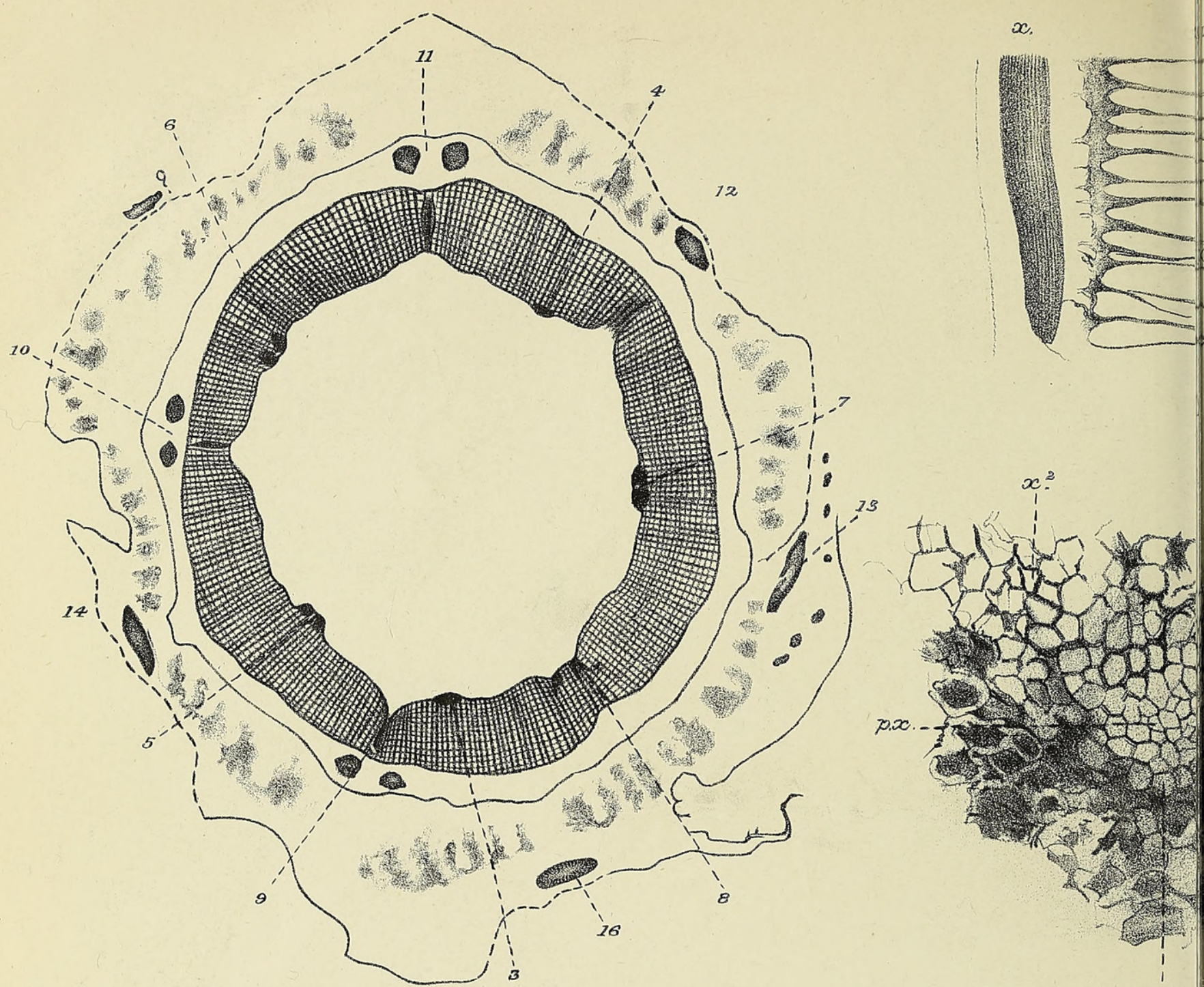

16.
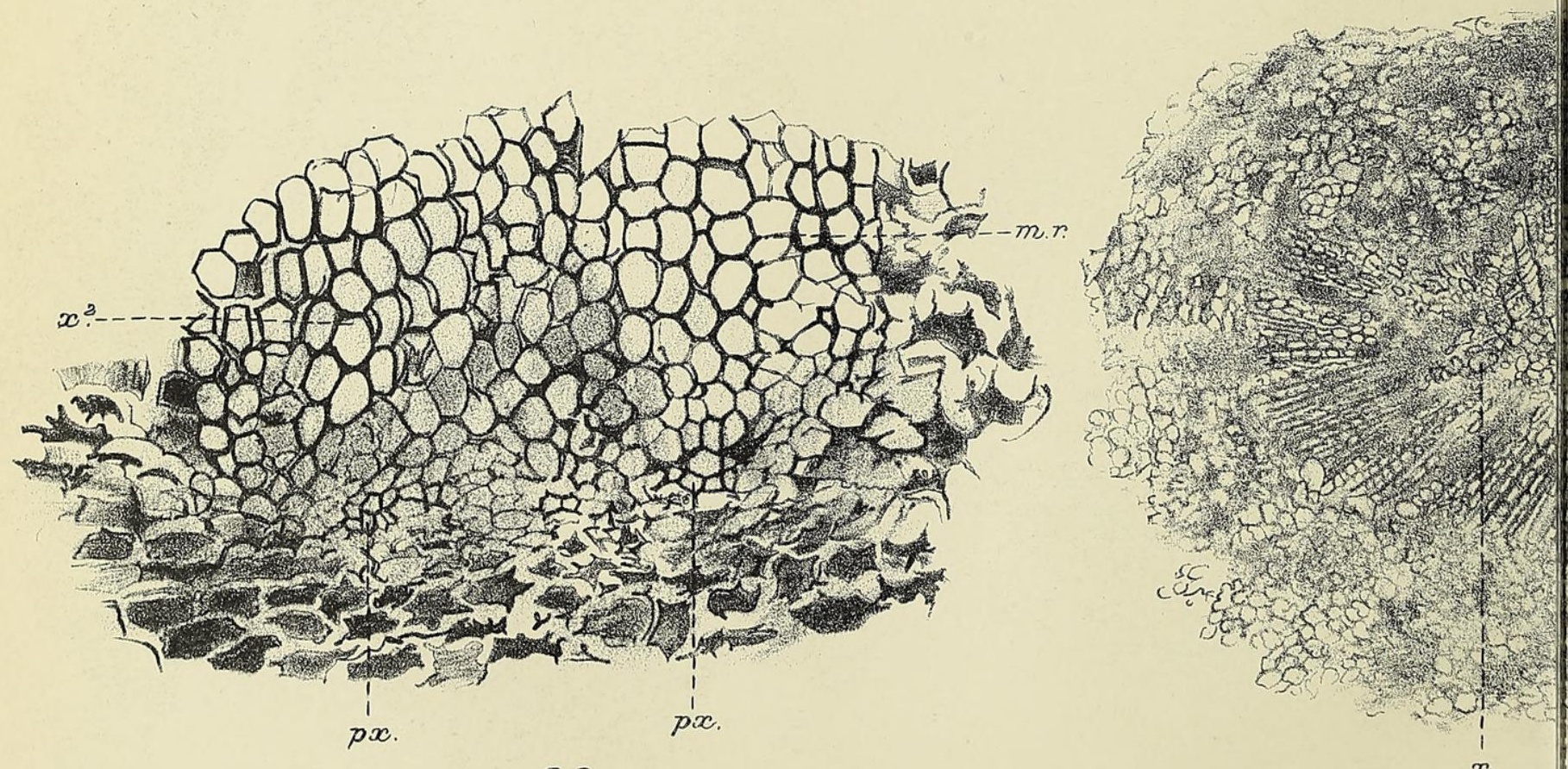

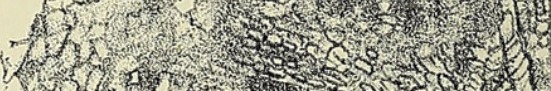

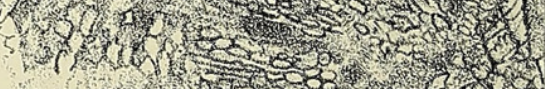

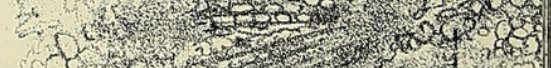
artor. (2) $27,2,1,101$

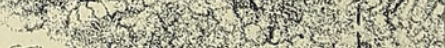

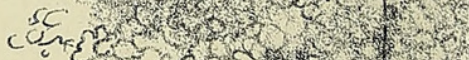

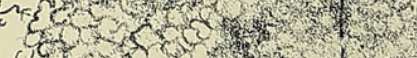

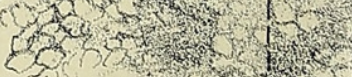
20 


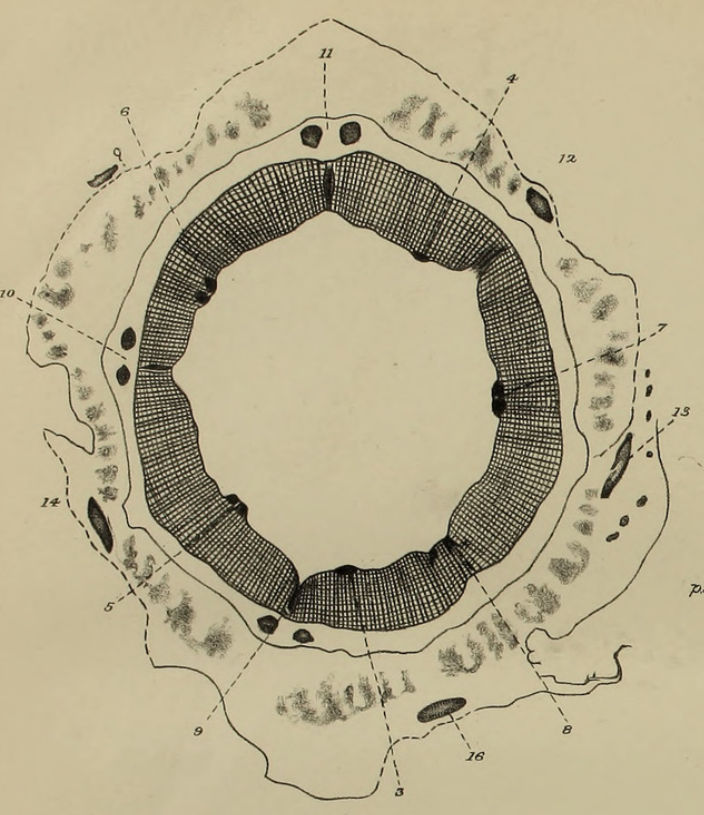

16

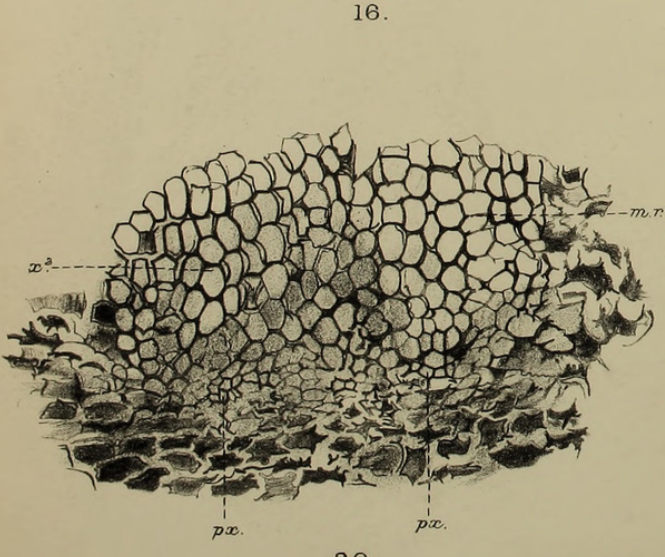

20
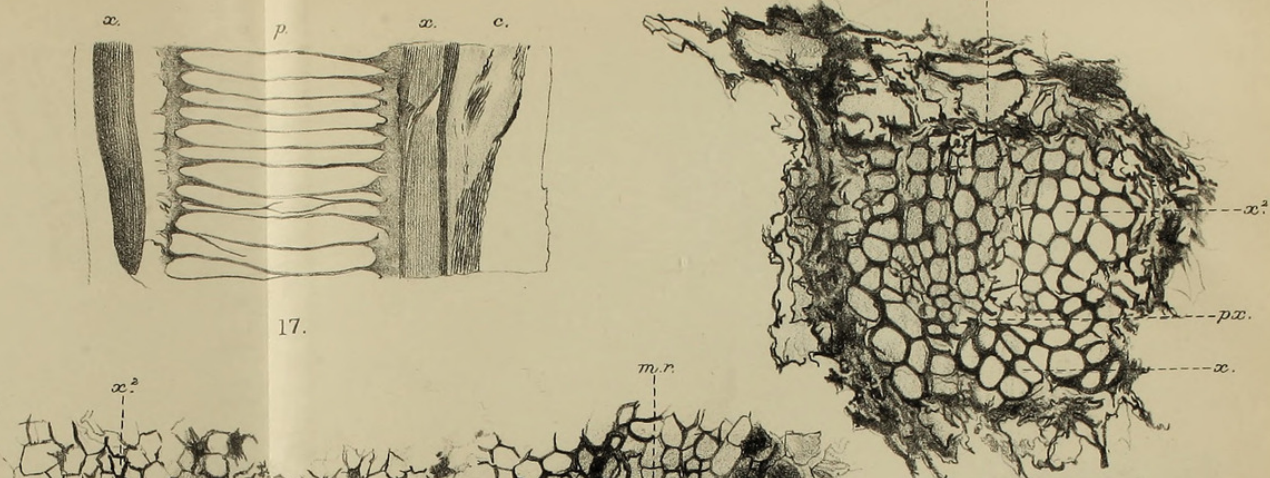

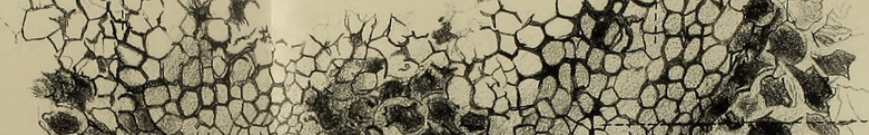

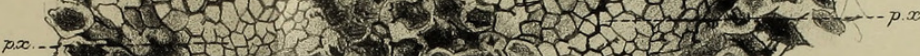

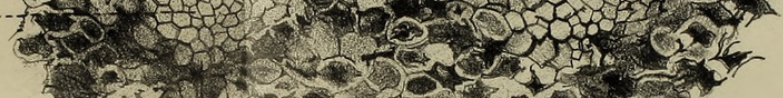

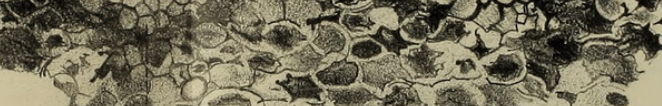
1. 0 -

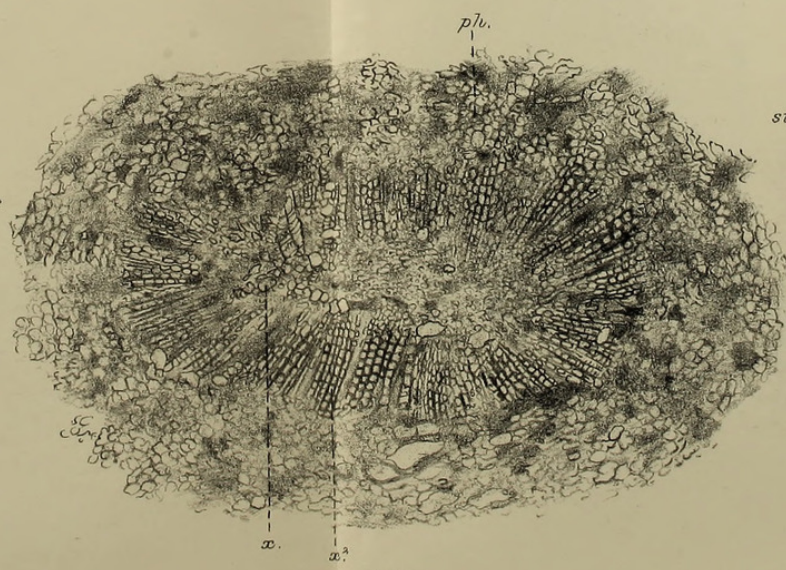

21.

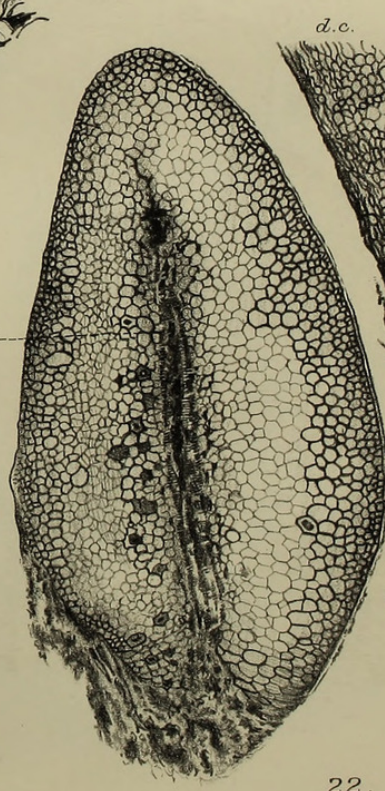

22 
Annals of Botany,

Vol. XXXII, PZ.XIV.

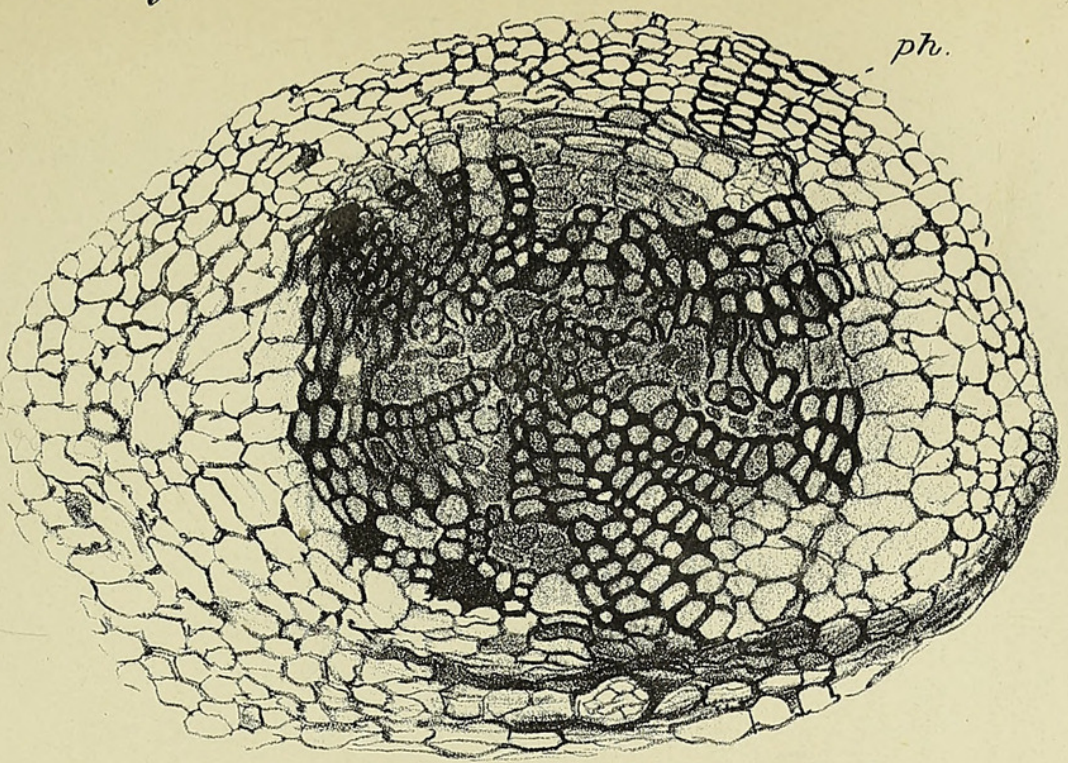

23.

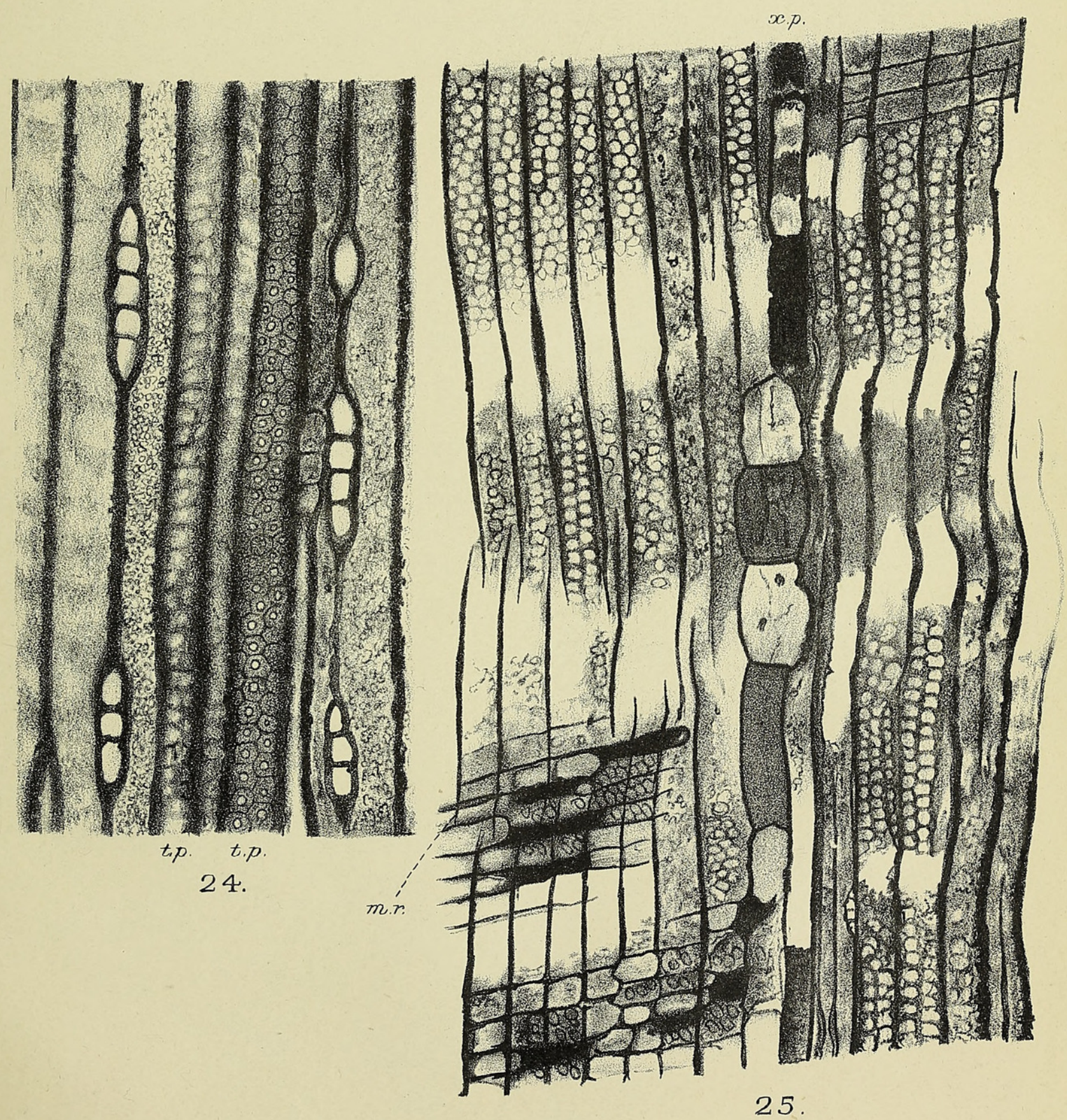




\section{$2 \mathrm{BHL}$ Biodiversity Heritage Library}

Scott, Dukinfield Henry. 1918. "The structure of Mesoxylon multirame." Annals of botany 32, 437-457. https://doi.org/10.1093/oxfordjournals.aob.a089684.

View This Item Online: https://www.biodiversitylibrary.org/item/238284

DOI: https://doi.org/10.1093/oxfordjournals.aob.a089684

Permalink: https://www.biodiversitylibrary.org/partpdf/320227

\section{Holding Institution}

Smithsonian Libraries

\section{Sponsored by}

Biodiversity Heritage Library

\section{Copyright \& Reuse}

Copyright Status: Not in copyright. The BHL knows of no copyright restrictions on this item.

This document was created from content at the Biodiversity Heritage Library, the world's largest open access digital library for biodiversity literature and archives. Visit BHL at https://www.biodiversitylibrary.org. 